\title{
Hydrothermal Activity in the Okinawa Trough Back-Arc Basin: Geological Background and Hydrothermal Mineralization
}

\author{
Jun-ichiro Ishibashi, Fumihiko Ikegami, Takeshi Tsuji, and Tetsuro Urabe
}

\begin{abstract}
The Okinawa Trough is a back-arc basin behind the Ryukyu trench-arc system and located along the eastern margin of the Eurasian continent. Sulfide and sulfate mineralization associated with hydrothermal activity has been recognized in ten hydrothermal fields in the Okinawa Trough. Hydrothermal mineralization recognized in these fields is commonly represented by coexisting occurrence of zinc- and lead-enriched polymetallic sulfides and abundant sulfate minerals. The mineralogy and geochemical signatures present has led researchers to suggest these areas may be a modern analogue for the formation of ancient Kuroko-type volcanogenic massive sulfide (VMS) deposits. Recent seafloor drilling during IODP (Integrated Ocean Drilling Program) Expedition 331 documented the subseafloor structure of a hydrothermal system at the Iheya North Knoll. Mineral textures and hydrothermal assemblages present in the drilled cores obtained from a hydrothermal mound in the proximal area are consistent with Kuroko-type mineralization. Based on geochemical studies, the intra-field diversity of mineralization commonly recognized in the Okinawa Trough can be explained by subseafloor phase separation of the hydrothermal fluid, which reflects shallow water depth (from 700 to $1,600 \mathrm{~m}$ ). The subseafloor phase separation may. play an important role to accumulate metal elements beneath the seafloor. Based on geophysical and geological studies, the Okinawa Trough is considered a back-arc basin in the rifting stage. Such a tectonic setting is characterized by development of normal faulting in brittle continental crust and frequent intrusion of a magma, which can be expected to provide favorable environment for development of a hydrothermal system
\end{abstract}

\section{Keywords}

Back-arc rifting • Kuroko-type deposit • Mineralization • Phase separation • Volcanic massive sulfide

J.-i. Ishibashi $(\bowtie)$

Department of Earth and Planetary Sciences, Faculty of Sciences, Kyushu University, Fukuoka 812-8581, Japan

Submarine Resources Research Project (SRRP), Japan Agency for Marine-Earth Science and Technology (JAMSTEC), Yokosuka 237-0061, Japan

e-mail: ishibashi.junichiro.779@m.kyushuu.ac.jp

F. Ikegami

Department of Earth and Planetary Sciences, Graduate School

of Sciences, Kyushu University, Fukuoka 812-8581, Japan
T. Tsuji

International Institute for Carbon-Neutral Energy Research (I2CNER), Kyushu University, Fukuoka 819-0395, Japan

Submarine Resources Research Project (SRRP), Japan Agency for Marine-Earth Science and Technology (JAMSTEC), Yokosuka 237-0061, Japan

T. Urabe

Department of Earth and Planetary Science, Graduate School of Science, The University of Tokyo, Tokyo 113-0033, Japan 


\subsection{Introduction}

Since the initial discovery in 1988 (Halbach et al. 1989), seafloor hydrothermal activity of the Okinawa Trough has been considered a modern analog to ancient Kuroko-type VMS (volcanogenic massive sulfide) deposits. Fouquet et al. (1991) proposed seafloor massive sulfide deposits in a back-arc setting showed more resemblance to the Kuroko-type deposits compared with those in the midocean ridge. Halbach et al. (1993) studied in detail mineralogy of sulfide ore samples collected from the Jade field in the Okinawa Trough, and concluded that the seafloor sulfide deposit is a modern analogue of the Kuroko-type deposits, based on strong similarities in the mineralogical and chemical composition of the polymetallic (zinc and lead enriched) sulfides present. Several researchers followed this idea in their reports for description of hydrothermal mineralization (e.g., Nakamura et al. 1989). Marumo and Hattori (1999) showed similarities are also found in occurrence of clay minerals formed by hydrothermal alteration. Glasby et al. (2008) argued that sulfide ore samples collected from hydrothermal fields in submarine volcanoes of the Izu-Bonin Arc showed greater similarities in chemical composition to that of the Kuroko-type deposits, although they recognized hydrothermal fields in the Okinawa Trough showed resemblance in the tectonic setting. In 2010, IODP Expedition 331 drilled through the active hydrothermal field at the Iheya North Knoll hydrothermal field, providing a unique opportunity to directly access the hydrothermal system below the seafloor (Takai et al. 2011, 2012). Mineral textures and assemblages present in the drilled cores obtained from a hydrothermal mound in the proximal area were consistent with those recognized in ancient Kuroko-type mineralization (Yeats et al. 2012; Yeats and Hollis 2013). Moreover, stratabound occurrences of base-metal mineralization and widespread hydrothermal alteration were documented across an area of over $500 \mathrm{~m}$ extent, which are comparable to ancient Kuroko-type deposits (Ishibashi et al. 2013).

The northeast (NE) Honshu is the type locality for Kuroko-type VMS deposits, where the Hokuroku District is especially known as many large deposits are concentrated. The Kuroko-type deposits are located in a narrow zone parallel to the arc and associated with a specific litho-tectonic domain that mainly consists of Neogene submarine volcanic rocks (e.g., Sato 1974). Numerous studies were devoted to understand formation of Kuroko-type VMS deposits which represent a significant crustal source of $\mathrm{Zn}-\mathrm{Pb}-\mathrm{Cu}-\mathrm{Ag}-\mathrm{Au}$ in Japan, based on analysis of samples collected during the mining boom period of 1960s (e.g., Ishihara 1974; Ohmoto and Skinner 1983). They established a concept that the Kuroko-type deposits formed at the discharge sites of submarine hydrothermal systems associated with silicic magmatic activity (e.g., Ohmoto 1996). However, several conflicting ore formation models have been proposed, and provoked continuing debate (e.g., Urabe and Marumo 1991; Ohmoto 1996). The Kuroko-type deposits are characterized by strata-bound and massive mineralization of diverse sulfide and sulfate minerals. However this style is difficult to be simply explained by the hydrogeology of a hydrothermal system. To make matters worse, the Kuroko mines in the northeast Japan were shut down during the 1980-1990s. Since then, samples are available only from archives (Glasby et al. 2008), and only a few studies have been published (e.g., Shikazono 2003; Urabe and Kubota 2004).

If it is the case that hydrothermal activity in the Okinawa Trough is a preferable modern analog to ancient Kuroko-type deposits, it would provide a rare window into the formation of Kuroko-type VMS deposits. In this Chapter, we review previous studies on hydrothermal mineralization in the Okinawa Trough to verify how it is analogous to characteristics of mineralization of the Kuroko-type deposits, which would be useful for further discussion on links between VMS mineralization and the regional geology of the Okinawa Trough back-arc basin. Tectonic activities, geological features (including the nature of volcanism), and its evolution are discussed in Sect. 27.2. Case studies on seafloor hydrothermal mineralization are introduced in Sect. 27.3. The characteristics and style of mineralization are discussed in relation to the tectonic setting of the Okinawa Trough back-arc basin in Sect. 27.4.

\subsection{Geological Setting of the Okinawa Trough}

\subsubsection{Tectonic Overview}

The Okinawa Trough is one of many back-arc basins located along the eastern margin of the Eurasian continent (Fig. 27.1). It extends for more than $1,200 \mathrm{~km}$ from the Japanese mainland to Taiwan along the Ryukyu Arc, and is characterized by active rifting structures and magmatism along the depression (Letouzey and Kimura 1986). In contrast to the other back-arc basins in western Pacific, previous study has shown that the Okinawa Trough lacks oceanic lithosphere (Nagumo et al. 1986; Hirata et al. 1991; Oshida et al. 1992). A recent seismic study revealed a minimum crustal thickness of only $8 \mathrm{~km}$ at the southernmost part (Klingelhoefer et al. 2009). Although this thickness might be thin compared with typical continental crust, the velocity gradient of the layer is too low to be interpreted as oceanic crust. From these lines of evidence, the Okinawa Trough is considered still to be in the nascent stage of back-arc basin formation. The slow extensional rate $(3.7 \pm 0.06 \mathrm{~cm} / \mathrm{year})$ 
Fig. 27.1 Tectonic setting of the Okinawa Trough back-arc basin. $\mathrm{N}-\mathrm{OT}, \mathrm{M}-\mathrm{OT}$, and S-OT represent the northern, middle, and southern Okinawa Trough, respectively. Star marks indicate localities of active hydrothermal fields, which are associated with subsection numbers in this text. Two red shaded areas represent the VAMP (Volcanic Arc Migration Phenomenon) area (Sibuet et al. 1987) and CVST (Cross-Backarc Volcanic Trail) area (Sibuet et al. 1998)

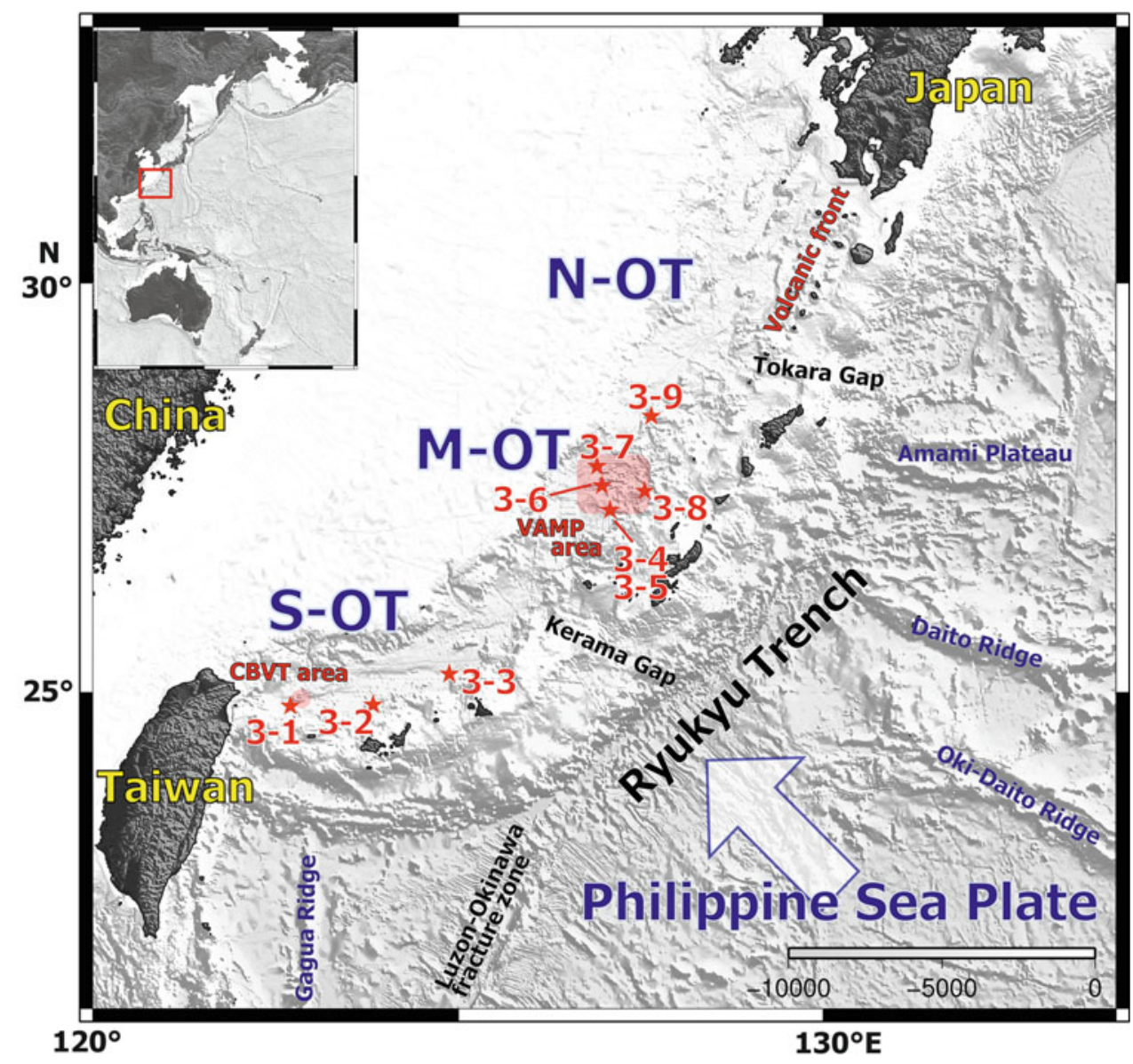

observed by means of the Global Navigation Satellite System, or GNSS (Kotake 2000) is also consistent with the view that seafloor spreading has not yet commenced.

\subsubsection{Geological Features and Volcanism}

Recent seismic profiles (Oikawa et al. 2009) have shown the Okinawa Trough is geologically complex both along and across its length (Fig. 27.2). The northern to middle part of the trough, which lies along the Kyushu to Amami Islands, consists of numerous half-grabens within and/or next to the massive Tokara Sub-Basin (Sibuet et al. 1987). The stratigraphy of this area was documented by the borehole "TO-KA1" (Nash 1979). On the basis of following correlations, the Shimajiri Group (SG) comprising Late Miocene to Pliocene terrigenous deposits, lies as the basement of the trough not only in the northern part but along its length (Kimura 1985). Such half-grabens rotated the Shimajiri Group, and they were later overlain by onlapping trough-infill deposits (Fig. 27.2a). The northern half of the trough had been long considered to be devoid of active volcanism (e.g. Kimura 1996). However, based on recent detailed mappings together with results of petrologic studies, Yokose et al. (2010) proposed that a chain of submarine knolls along the North Okinawa Trough would be assigned as an extension of the volcanic front of the Ryukyu Arc that is identified as volcanoes in the Tokara Islands.

In the middle to southern Okinawa Trough, there is a remarkable change in the topography of the trough. The trough floor is lowered and the continental slope becomes steeper (Fig. 27.1). Such a topographical change is accompanied by en echelon intra-trough grabens (Kimura 1985). While the volcanic front in the Ryukyu Arc disappears from the sea-surface in west area of the Iwo-Torishima Is., an area of extensive intra-trough volcanism along the Iheya Graben occurs in the middle of the Okinawa Trough. Sibuet et al. (1987) inferred this was a product of the volcanic arc migrating into the back-arc basin, and named it the Volcanic Arc Migration Phenomenon, or VAMP area. Although the volcanism takes place within the Okinawa Trough, its compositions consistently vary from rhyolite to basalt (Ishikawa et al. 1991; Shinjo and Kato 2000). As a result of such extensive volcanism, the VAMP area is spotted with regions of anomalously high heat flow (Yamano et al. 1986) and several hydrothermal fields (Ishibashi and Urabe 1995). 

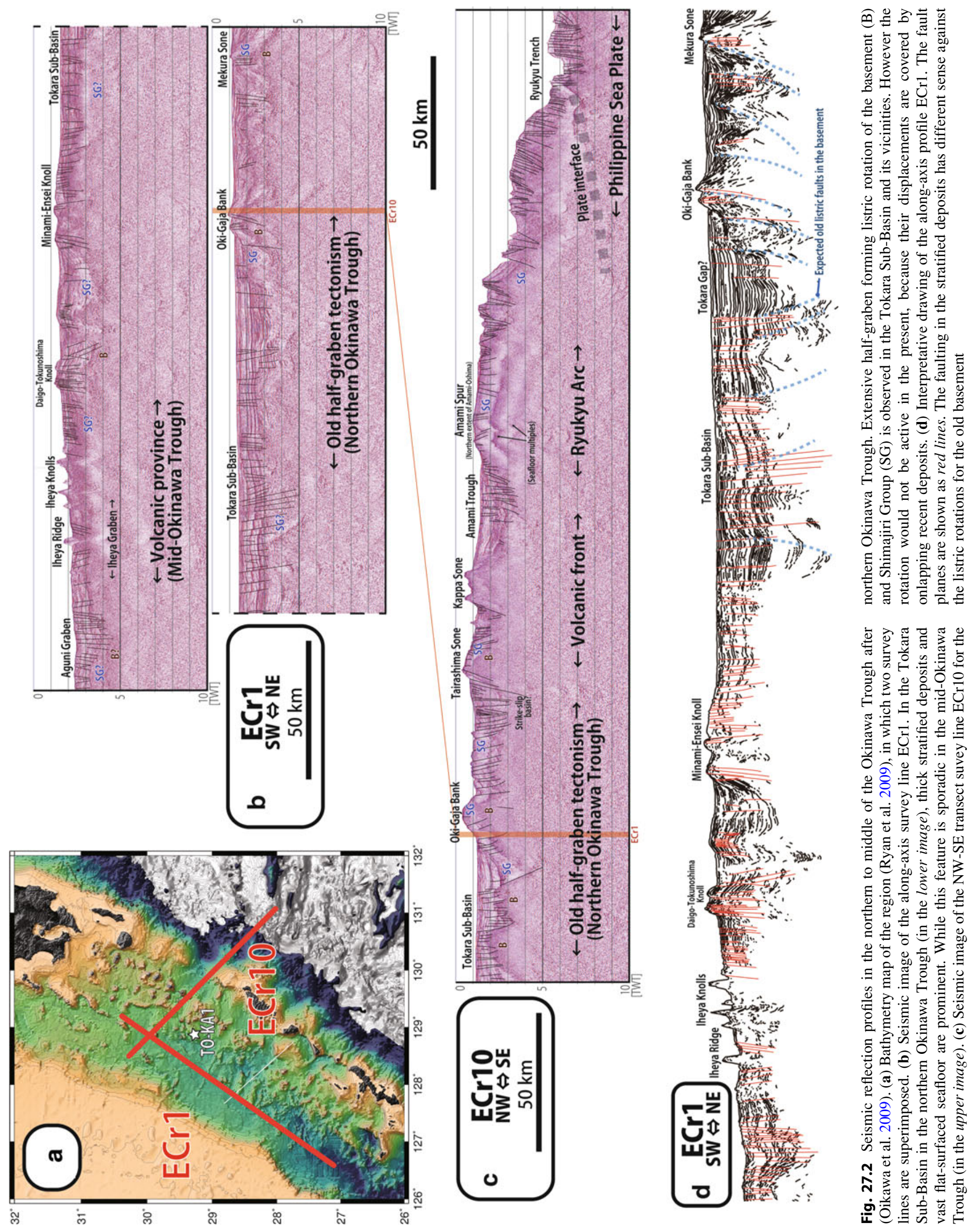
The southernmost area which is close to Taiwan Is. has the topographically lowermost trough floor throughout the Okinawa Trough (Fig. 27.1). Previous surveys on the crustal thickness in the area documented the thinned nature of the continental crust, which is less than $20 \mathrm{~km}$ thick (Lee et al. 1980; Hirata et al. 1991; Klingelhoefer et al. 2009), whereas thicker crust occurs in the middle (Murauchi et al. 1968; Nagumo et al. 1986) and northern parts (Iwasaki et al. 1990) of the trough. Such geophysical evidence suggests that backarc basin formation is most pronounced in the southernmost part of the Okinawa Trough. This area hosts major volcanic alignment which crosses the central graben, and called as the Cross-Backarc Volcanic Trail, or CBVT (Sibuet et al. 1998). Chronological variations of the volcanism suggest complex backgrounds related to the collision in Taiwan (Shinjo 1999; Shinjo et al. 1999). Lin et al. (2004) inferred that a slab window originated from the subducting Gagua Ridge on the Philippine Sea Plate was the cause of such volcanism. Possible signs of magma chambers at the lower crust beneath the CBVT have been observed (Lin et al. 2009).

\subsubsection{Origin and Evolution}

Multiple stages of evolution were proposed to explain the origin of the Okinawa Trough (e.g. Lee et al. 1980; Kimura 1996; Miki 1995). The geographical order and timing of the initiation of rifting still remains quite controversial. The geological reconstruction proposed by Kimura (1985, 1990, 1996) provided a schematic evolution for the entire Okinawa Trough, with two stages of rifting in the Pliocene (6-4 Ma) and Pleistocene to present (2-0 Ma). Kimura $(1985,1990,1996)$ argued that extensive rifting took place between the area of the current continental shelf and Ryukyu Arc in the first stage. The deposition of Shimajiri Group, which was widely prograding from the continental shelf to Ryukyu Trench (Sibuet et al. 1998; Park et al. 1998) took place during this event. Across the unconformity that was associated with subaerial exposure (Kimura 2000), the second stage of rifting was marked by the rapid subsidence and deposition of onlapping thick trough-infills which eventually shaped the present Okinawa Trough. Submarine channels and meanders at the trough floor (Kimura et al. 2001), as well as limestone outcrops discovered from a water depth of $\sim 1,400 \mathrm{~m}$ (Shinjo et al. 2001), indicate the remarkable rate of the subsidence. At least in the southernmost area of Okinawa Trough, this stage is thought to be still in progress with the westward migration towards Taiwan (Wang et al. 2000).

On the other hand, the onshore studies have shown that the recent advances on the studies of coral development in Pleistocene provided the spatiotemporal yield for the backarc basin formation, which is possibly comparable to the second stage of the rifting. Formation of the back-arc basin would disturb the terrigenous supply from the continent and enable the growth of coral reefs in the arc. In fact, the oldest reef deposits in the Ryukyu Islands formed at 1.45-1.65 Ma in the northern to middle part of the Islands, while the dating never predates $1 \mathrm{Ma}$ at the southernmost Yaeyama Islands (Iryu et al. 2006). It is therefore assumed that the subsidence of the Okinawa Trough started at the northern to middle part in the Early Pleistocene, prior to development in the south. A paleostress study supports such a view of southwestward migration of the rifting (Otubo and Hayashi 2003). In the Ryukyu Islands, however, it is believed that a large scale environmental change from the marginal highlands to the island chain took place somewhat coincidentally. Pollen analysis in the Okinawa Island spotted the disappearance in the mountains of 1,000-1,500 m height which apparently enabled the vegetation of cool climate trees in $1.2-0.8 \mathrm{Ma}$ (Kuroda and Ozawa 1996). Phylogenetic reconstruction of insects also provided an implication for the timing of the isolation of the islands as in the form of group. It is estimated that Amami-Okinawa, Yaeyama and Taiwan were likely to be branched simultaneously around $1.55 \mathrm{Ma}$ (Osozawa et al. 2013). Although the detailed context of events and their localities may still require further investigations, the ongoing tectonics in the Okinawa Trough can be well understood within the framework of a developing Quaternary back-arc basin.

\subsection{Case Studies in Hydrothermal Activity and Mineralization in the Okinawa Trough}

\subsubsection{Daiyon-Yonaguni Knoll Hydrothermal Field}

The Daiyon-Yonaguni Knoll hydrothermal field is situated in an elongated valley with a length of approximately $1,000 \mathrm{~m}$ and a width of approximately $500 \mathrm{~m}$, and lies adjacent to the Daiyon-Yonaguni Knoll (one of the seamounts that delineate a volcanic belt) (Fig. 27.3). Active hydrothermal sites align north-south, which may be related to a fault control on hydrothermal flow. Observations during dive surveys indicate the elongated valley is covered mainly with muddy sediment, except for active hydrothermal sites, and that the northern slope of the valley has volcanic breccia (Suzuki et al. 2008).

A diverse style of fluid emanations occurs within the Daiyon-Yonaguni Knoll hydrothermal field (Inagaki et al. 2006; Konno et al. 2006; Suzuki et al. 2008). A large chimney-mound complex called the Tiger site, which is approximately $10-\mathrm{m}$ high, is located near the boundary between the slope of the knoll and sediment seafloor at water depth of $\sim 1,370 \mathrm{~m}$. Vigorous venting of blackish-smoky fluids 

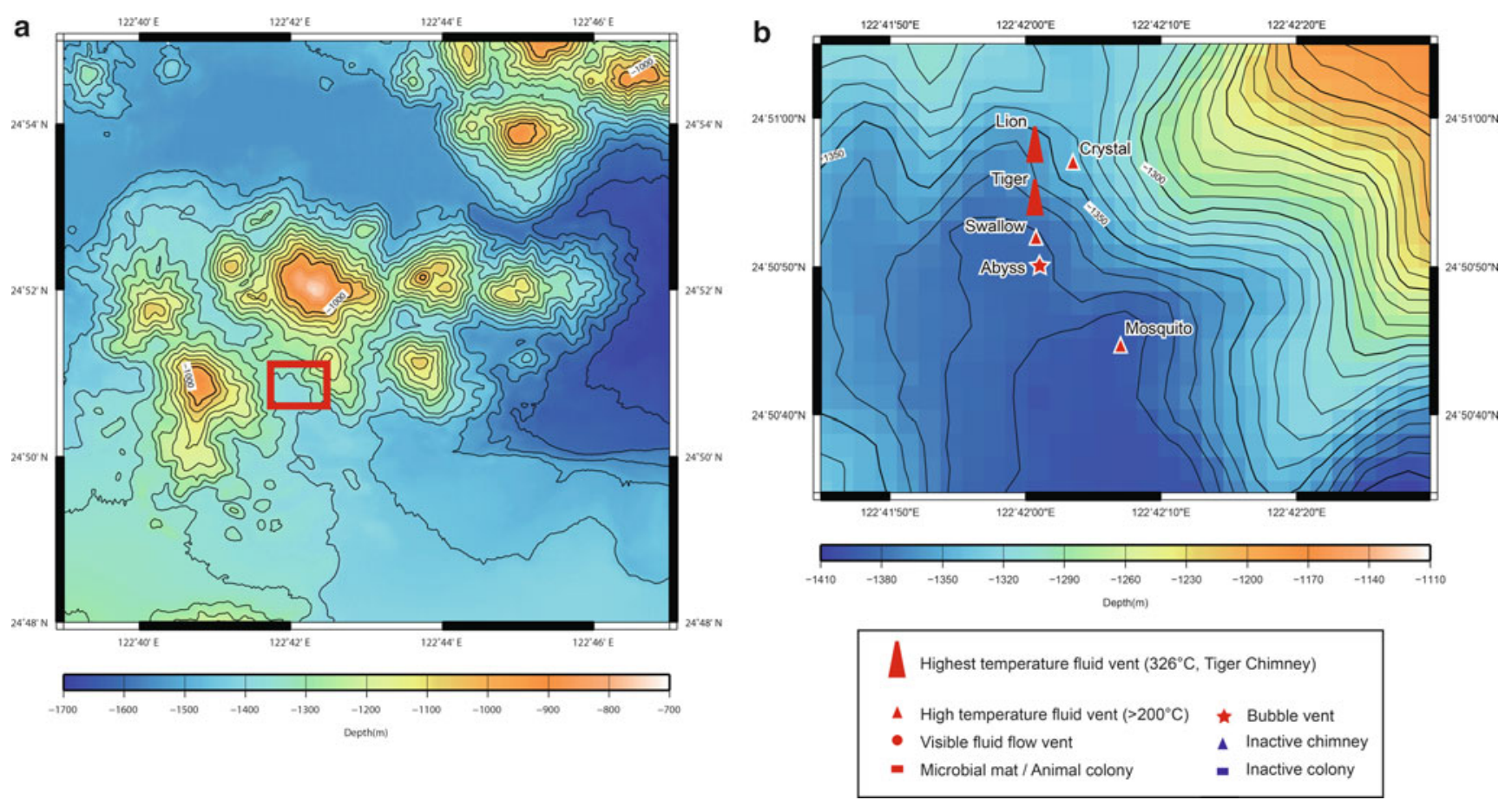

Fig. 27.3 (a) Topography of the Daiyon-Yonaguni Knoll (b) Localities of active fluid venting in the Daiyon-Yonaguni Knoll hydrothermal field

up to $328{ }^{\circ} \mathrm{C}$ has been recorded from the basal part of the mound complex, which seems to mark the central part of the present hydrothermal activity in the field. On the other hand, clear fluid venting with the highest temperature of $310^{\circ} \mathrm{C}$ was observed at the top of the same chimney at the Tiger site at water depth of 1,362 m. Another large chimney-mound complex called the Lion site (located at just $50 \mathrm{~m}$ north of the Tiger site) hosts smokers venting vigorously similar blackish smoky fluid at $326{ }^{\circ} \mathrm{C}$. Another mound structure (named as Crystal Site) at about $100 \mathrm{~m}$ east of the Tiger site was recognized by dense colony of vent specific animals. Venting of clear fluid with the highest temperature of $220{ }^{\circ} \mathrm{C}$ was observed at the foot of the mound, which was accompanied with discharge of significant amount of liquid $\mathrm{CO}_{2}$ droplets. Liquid $\mathrm{CO}_{2}$ emanation from altered sediment has been observed in many places around the active hydrothermal mounds (Inagaki et al. 2006; Konno et al. 2006). In the southern part of the hydrothermal field (the Abyss Vent site), diffusive fluid venting was observed from the seafloor which is covered with sediment associated whitish hydrothermal crusts (Inagaki et al. 2006). Further south, inactive or diffuse venting from small chimney structures has been recognized, although the area has not been well explored.

Mineralization in the Daiyon-Yonaguni Knoll hydrothermal field was studied in detail by Suzuki et al. (2008). According to this study, the diverse range of sulfide and sulfate mineral deposits can be classified into five groups; (i) anhydrite-rich chimneys, immature precipitates including sulfide disseminations in anhydrite; (ii) massive $\mathrm{Zn}-\mathrm{Pb}-\mathrm{Cu}$ sulfides, consisting of sphalerite, wurtzite, galena, chalcopyrite, pyrite, and marcasite; (iii) Ba-As chimneys, composed of barite with sulfide disseminations, sometimes associated with realgar and orpiment overgrowth; (iv) Mn-rich chimneys, consisting of carbonates (calcite and magnesite) and sulfides (sphalerite, galena, chalcopyrite, alabandite, and minor amount of both tennantite and enargite); and (v) pavement, silicified sediment including abundant native sulfur or barite.

Suzuki et al. (2008) demonstrated a link between the mode of sulfide/sulfate mineralization and geochemistry of fluid emanations. The sulfide/sulfate mineralization (groups i-iii) was dominantly observed in chimney-mound structures in the proximal area (the Tiger site and Lion site), which often host vigorous venting of high temperature and slightly $\mathrm{Cl}$-enriched fluid $(\mathrm{Cl}$ concentration of the fluid is higher than that of seawater). In contrast, the sulfide/ carbonate mineralization (group iv) and the silicified sediment (group v) were found in the distal area, which are associated with clear fluid venting and/or diffusive fluid emanation. These fluids showed Cl-depleted chemistry and sometimes were associated with discharge of $\mathrm{CO}_{2}$ liquid droplets. Cl-depleted clear fluid venting was exceptionally observed in the proximal area, at the very top of the chimney at Tiger site. And in the same chimney, carbonate minerals were identified, which follows the same link between the mineralization and fluid chemistry. In addition, Gena et al. 

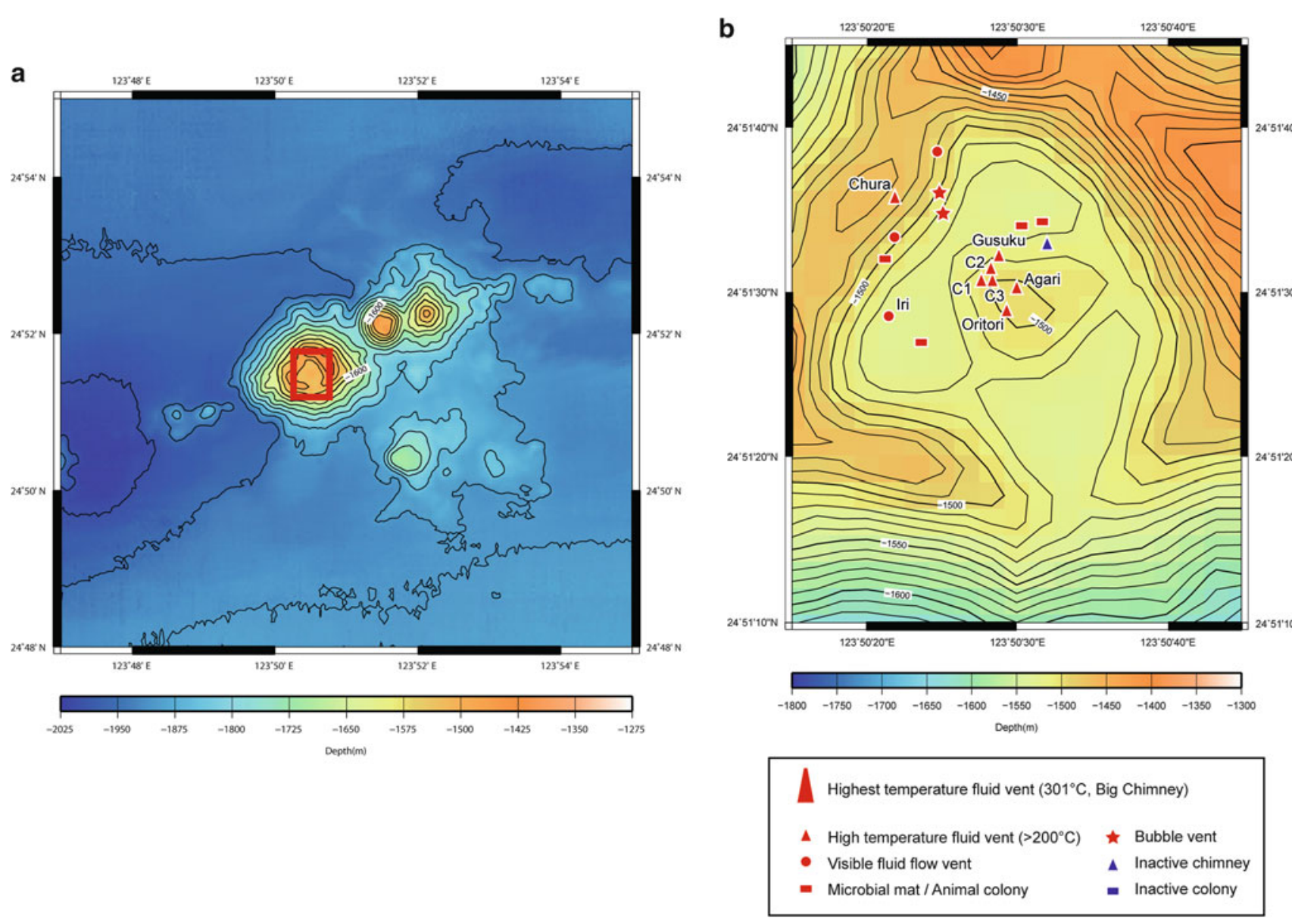

Fig. 27.4 (a) Topography of the Hatoma Knoll (b) Localities of active fluid venting in the Hatoma Knoll hydrothermal field

(2013) documented occurrence of $\mathrm{Pt}-\mathrm{Cu}-\mathrm{Fe}$-bearing bismuthinite and Sn-bearing chalcopyrite in the active chimney at the Tiger site. They were attributed to have precipitated as metastable phase at a temperature above $300{ }^{\circ} \mathrm{C}$ based on the fluid inclusion data.

\subsubsection{Hatoma Knoll Hydrothermal Field}

The Hatoma Knoll hydrothermal field is located inside the summit crater of the Hatoma Knoll (Fig. 27.4). At the center of the summit crater, which is approximately $600 \mathrm{~m}$ in diameter, a dacite cone hosting large active chimney structure was recognized at a water depth of 1,470-1,485 m (Watanabe 2001). Hydrothermal activity has also been observed in several sites surrounding the central cone at water depth about $1,490 \mathrm{~m}$, where the seafloor is covered with (altered) sediment. Vigorous venting of clear hydrothermal fluid up to $301{ }^{\circ} \mathrm{C}$ at the central cone seems to mark the central part of the present hydrothermal activity in the field. Emanation of liquid $\mathrm{CO}_{2}$ droplets was observed at several active sites including the central cone (Shitashima et al. 2007).
According to the previous study (Okamoto et al. 2002; Nakano et al. 2008), mineralization in the Hatoma Knoll field can be classified into three groups; (i) anhydrite-rich chimneys, immature precipitates including sulfides (sphalerite and pyrite) disseminations in anhydrite; (ii) massive $\mathrm{Zn}$ $\mathrm{Pb}-\mathrm{Cu}$ sulfides, consisting of sphalerite, wurtzite, galena, tennantite-tetrahedrite, chalcopyrite and pyrite, and sometimes associated with non-stoichiometric As-sulfide; and (iii) Ba-As chimneys, composed of barite and sulfides disseminations sometimes associated with As-sulfide and/ or kermesite which is likely to be secondary minerals originated from stibnite. Other than these sulfide/sulfate minerals, glob of native sulfur was sometimes recognized as attached to the ore samples.

The association between the mode of sulfide/sulfate mineralization and geochemistry of fluid emanations is relatively simple. All of the active chimneys venting high temperature fluids are predominantly composed of anhydrite, and the fluid chemistry was $\mathrm{Cl}$-depleted without any exception. Barite bearing chimneys were always inactive chimneys. On the other hand, the abundant occurrences of sulfides have only been found in massive blocks which were 

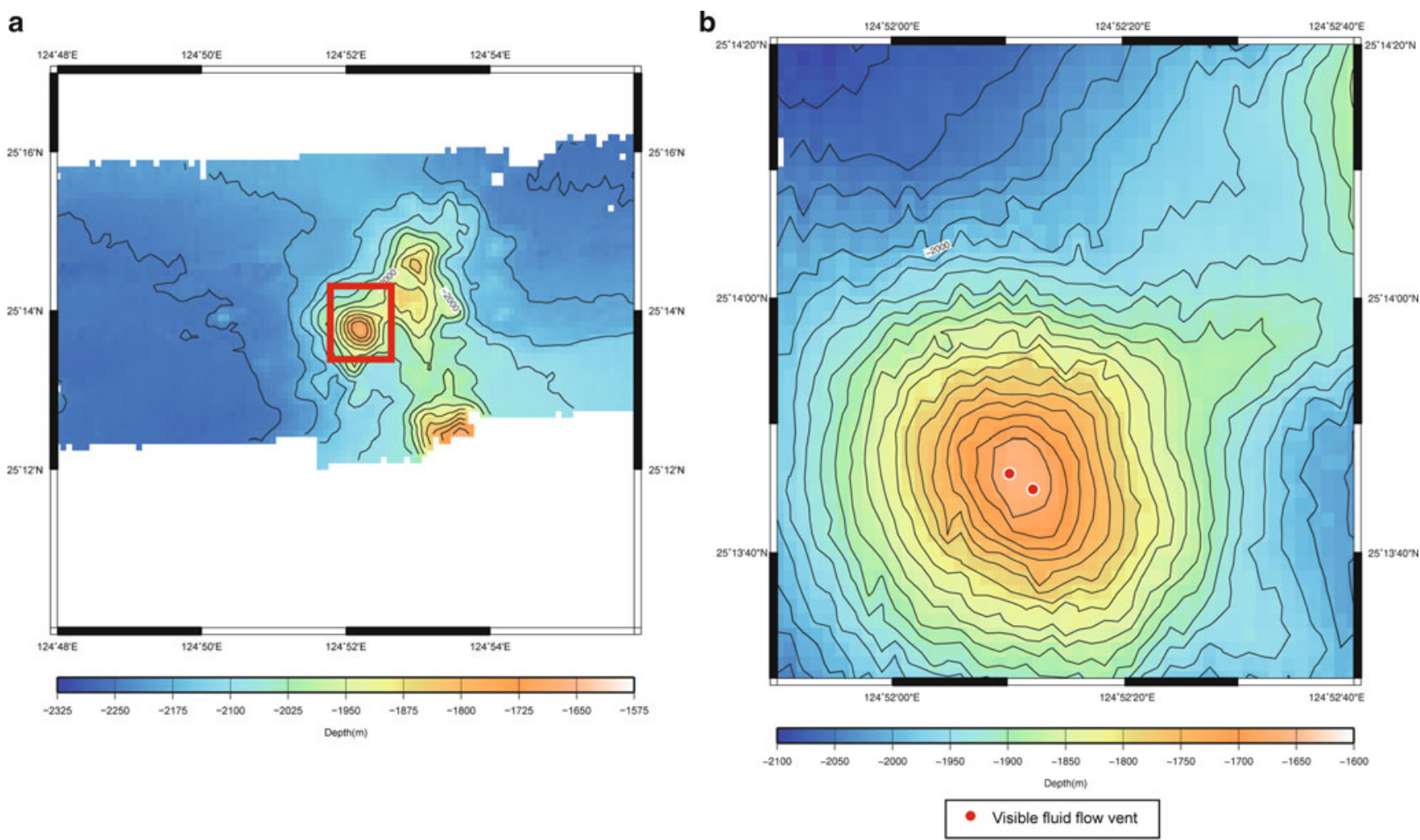

Fig. 27.5 (a) Topography of the Irabu Knoll (b) Localities of active fluid venting in the Irabu Knoll hydrothermal field

sampled from the mound structure, sometimes half buried in the seafloor.

There is a report that a $\mathrm{Cu}$-rich sulfide sample approximately $5 \mathrm{~cm}$ in size was dredged from a small knoll $\left(24^{\circ} 46.0^{\prime} \mathrm{N}\right.$, $123^{\circ} 59.0^{\prime} \mathrm{E}$, water depth $=1,474 \mathrm{~m}$ ) near the Hatoma Knoll (Watanabe et al. 1995). In addition, east of the Hatoma Knoll, Tarama Knoll $\left(25^{\circ} 06^{\prime} \mathrm{N}, 124^{\circ} 32^{\prime} \mathrm{E}\right.$, water depth $\left.=1,490 \mathrm{~m}\right)$ has been known as to host Fe-rich oxides mineralization in more than $100 \mathrm{~m}$ wide area (Yamanaka et al., Chap. 40).

\subsubsection{Irabu Knoll Hydrothermal Field}

Hydrothermal activity has been observed both at the top of West seamount and at the summit depression of the East seamount (Fig. 27.5). More intense activity was observed on the West seamount, where clear fluid emanations with the temperature of $151{ }^{\circ} \mathrm{C}$ were recorded in 2000 (Matsumoto et al. 2001) and $67^{\circ} \mathrm{C}$ was recorded in 2011 (Fukuba et al., Chap. 39). Along a steep slope of both the West and East seamounts, continuous exposures of fresh basaltic pillow lava were observed (Matsumoto et al. 2001). Magmatism of the Irabu Knoll has been considered to occur at the cross point of an axial part of the Yaeyama Central Graben and the volcanic front of the Ryukyu trench-arc-backarc system.
Mineralization in the Irabu Knoll field was studied with great interest, since the hydrothermal activity is probably hosted by a basaltic magma (Watanabe et al. 2006). Massive sulfide samples collected from the West seamount consist of dominant sphalerite, with subordinate amounts of chalcopyrite, galena and tennantite-tetrahedrite and with some realgar. Chimney-like samples and gangue minerals-rich samples were also recovered. In a sample of massive sulfide collected from the East seamount, primary bornite and secondary covellite were identified. In summary, mineral associations of the sulfide samples did not show distinctive characteristics from other hydrothermal fields in the Okinawa Trough, with exception for a few minor minerals (Watanabe et al. 2006).

\subsubsection{Hakurei Hydrothermal Field in the Izena Hole}

The Hakurei field is located at the bottom of the depression of the Izena Hole (which has also been termed as the Izena Cauldron), at water depths of 1,600-1,610 m (Fig. 27.6a, b). The Izena Hole is situated along the southwestern continuation of a chain of Quaternary volcanoes of the Ryukyu arc (Shinjo et al. 1999), while its location can also be considered as the 
a

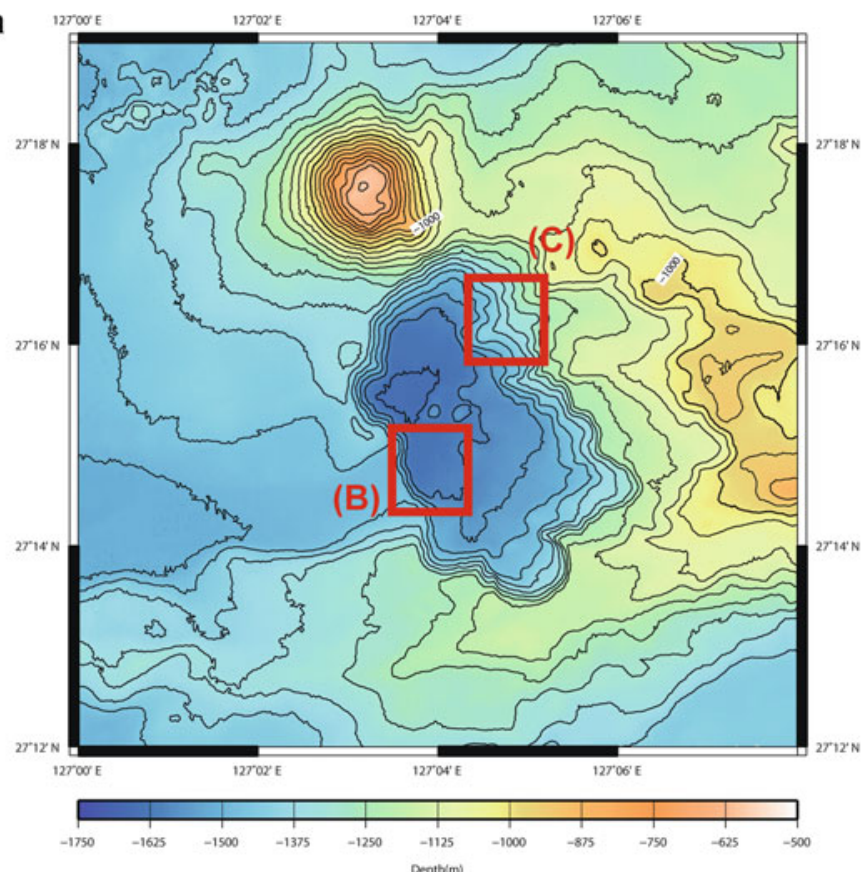

b
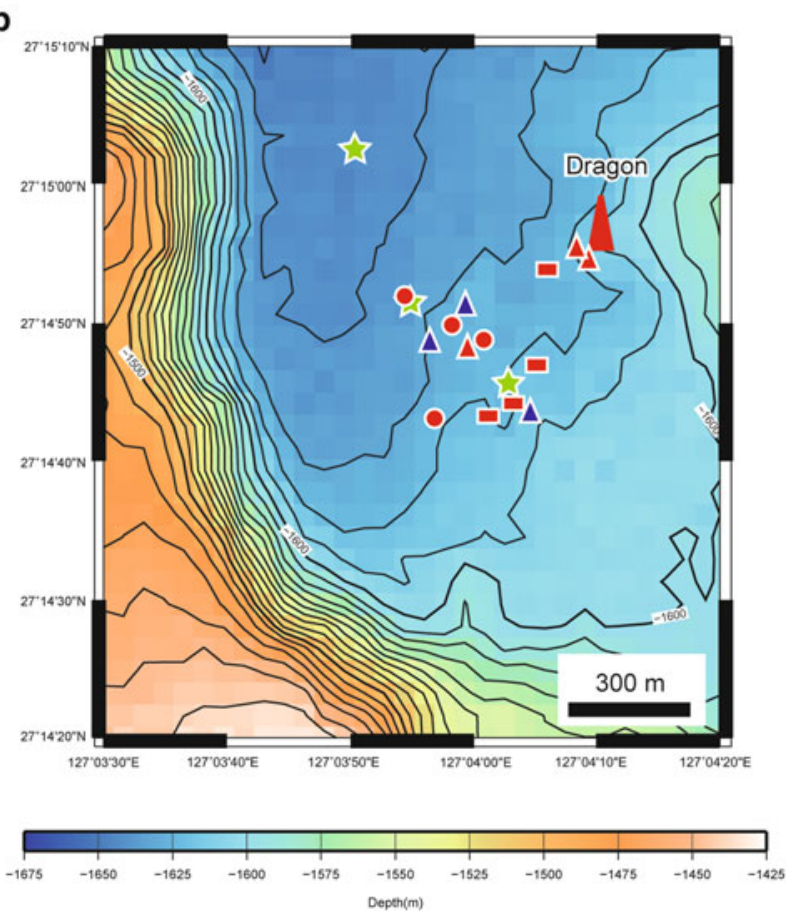

Highest temperature fluid vent $\left(326^{\circ} \mathrm{C}\right.$, Dragon Chimney)

4. High temperature fluid vent $\left(>200^{\circ} \mathrm{C}\right)$

- Visible fluid flow vent

* Siulfur crust

- Microbial mat / Animal colony

A Inactive chimney

- Inactive colony
C
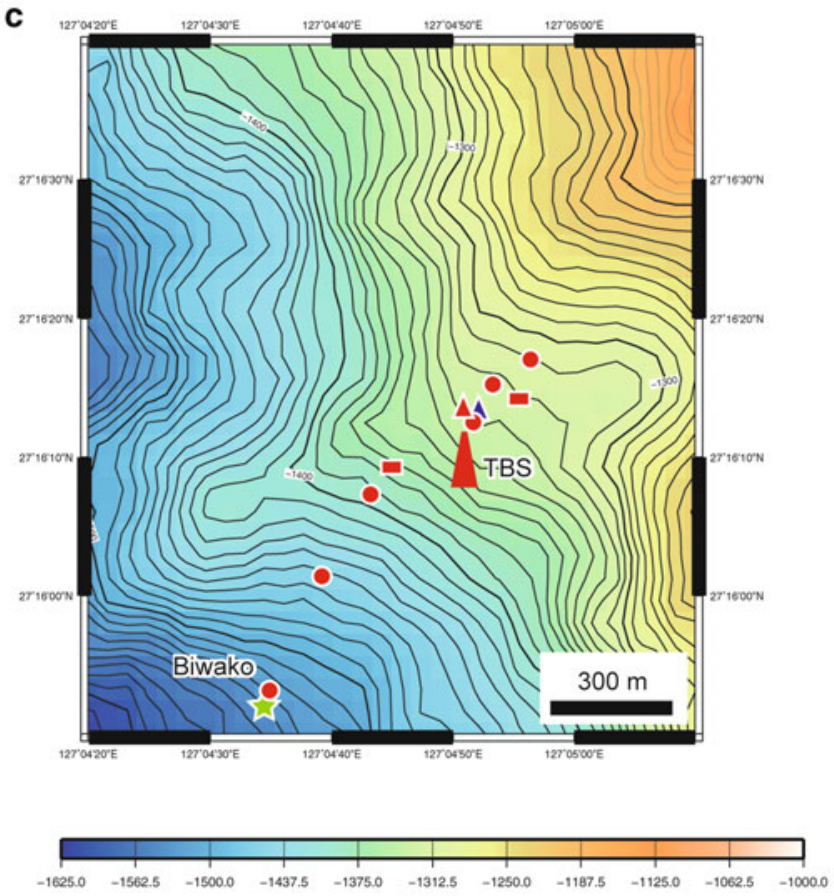

$\operatorname{Depth(m)}$

Highest temperature fluid vent $\left(320^{\circ} \mathrm{C}\right.$, TBS Chimney)

- High temperature fluid vent $\left(>200^{\circ} \mathrm{C}\right) \star$ Siulfur crust

- Visible fluid flow vent

A Inactive chimney

- Microbial mat / Animal colony

- Inactive colony

Fig. 27.6 (a) Topography of the Izena Hole (b) Localities of active fluid venting in the Hakurei field (c) Localities of active fluid venting in the in the Jade field 
eastern end of the Aguni rift graben segment (Halbach et al. 1993). The Izena Hole is a rectangular shaped depression about $6 \times 3 \mathrm{~km}$. Abundant tuff breccia and woody pumice exposed on the slopes, and a center-cone like small knoll consisted of dacitic lava recognized at the center of the Hole, are evidence for recent magmatic activity (Kato et al. 1989; Kato 1990).

Hydrothermal activity has been observed over an area exceeding $500 \mathrm{~m}$ length during ROV studies (Ishibashi et al. 2014). Vigorous high temperature fluid venting in the Hakurei field was often associated with a complex chimney structure which was more than $10 \mathrm{~m}$ in height and equipped with well-developed flange structure. Effluent of high temperature fluid up to $326^{\circ} \mathrm{C}$ was observed from the edges of a few meters long flange at the "Dragon" chimney located at a water depth of $1,600 \mathrm{~m}$.

The Hakurei field has been explored intensively by JOGMEC (Japan Oil, Gas and Metals National Corporation) under a framework of the ocean energy and mineral resources development program since 2008. More than a hundred of drillings with BMS (Benthic Multi-coring System) have been conducted, and Zn-rich polymetallic sulfide mineralization was extensively recognized in the Hakurei field (METI 2013). BMS drilling was also conducted for scientific purpose during the TAIGA project (Ishibashi et al., Chap. 42). A sequence of core samples of $6 \mathrm{~m}$ length was successfully obtained and occurrence of $\mathrm{Cu}$-rich sulfide mineralization was recognized (Yoshizumi et al., Chap. 43).

\subsubsection{Jade Hydrothermal Field in the Izena Hole}

The Jade field is located at an inside slope of the north-eastern wall of the Izena Hole (Cauldron) at a water depth of 1,550-1,300 $\mathrm{m}$ (Fig. 27.6a, c). This field is named as "JADE" in commemoration of Japan-Deutche collaboration during the SO-56 cruise of German Research Vessel Sonne, which accomplished the first discovery for the seafloor hydrothermal activity around Japan (Halbach et al. 1989). Hydrothermal activity was recognized in an area of $500 \times 300 \mathrm{~m}$. Venting of hydrothermal fluid up to $320^{\circ} \mathrm{C}$ at the TBS chimney at water depth of $1,350 \mathrm{~m}$ seems to mark the central part of the present hydrothermal activity in the field. Active chimneys associated with moderate to high temperature fluid venting are concentrated in around the TBS chimney. Diffusive shimmering vents and inactive chimneys have been recognized, along the active venting, in a NE-SW direction (Nakamura et al. 1989). Emission of liquid $\mathrm{CO}_{2}$ was identified at both extensions of the chimney line (Sakai et al. 1990). At the southwestern extension of the chimney line, thick layered consolidated structure plausibly consisted of amorphous silica and native sulfur was recognized at $\sim 500 \mathrm{~m}$ apart from the
TBS chimney. In the vicinity, diffusive venting of hydrothermal fluid of $104{ }^{\circ} \mathrm{C}$ associated with liquid $\mathrm{CO}_{2}$ bubble was located, which was named as the Biwako vent (Ishibashi et al. 2014). About $3 \mathrm{~km}$ southwest of the Biwako Vent, the Hakurei field is located; however, the sandwiched area between the Jade and Hakurei fields has not been explored.

Mineralization in the Jade field was studied at first using massive samples collected by a TV-controlled deep-sea grab system during SO-56 cruise (Halbach et al. 1989). Sphalerite and galena were the principal minerals, which are accompanied by pyrite, marcasite, chalcopyrite, tetrahedrite-tennantite, barite, amorphous silica and anglesite. Halbach et al. (1993) distinguished five ore types from the collected samples; (i) $\mathrm{Zn}-\mathrm{Pb}$ rich sulfide ore, massive sulfide composed of sphalerite, galena, pyrite, and chalcopyrite; (ii) $\mathrm{Ba}-\mathrm{Zn}-\mathrm{Pb}$ sulfide ore, consists of a matrix of euhedral to anhedral barite with sphalerite and tennantite-tetrahedrite; (iii) Massive $\mathrm{Zn}-\mathrm{Cu}$-rich sulfide slabs, dominated by sphalerite and chalcopyrite, but contain pyrite, marcasite, covellite, realgar, galena and a Ag-Cu-sulfide; (iv) Fe-rich replacement ore, which represents fragments of mature chimneys and (v) Zn-Pb-rich impregnation ore consists of thin stringers and veinlets filled with coarse-grained sulfides in strongly altered siliceous host rocks.

Several geochemical studies have been conducted for these mineral deposits. Systematic studies on fluid inclusions (Lüders et al. 2001, 2002; Lüders and Niedermann 2010) demonstrated evidence for subseafloor phase separation and its influence on the mineralization. Lead isotope data from ores, igneous rocks and sediments suggested that both surrounding sediments and volcanic rocks contributed comparable amounts of lead to the deposit (Halbach et al. 1997). Zeng et al. (2009) reported minor elements composition and U-series isotope data of sulfide/ sulfate deposits. Noguchi et al. (2011) reported ${ }^{87} \mathrm{Sr} /{ }^{86} \mathrm{Sr}$ data for barite collected from the Jade and Hakurei fields, which suggest a significant contribution of sediment.

\subsubsection{Clam Hydrothermal Field Along the lheya Ridge}

The Clam hydrothermal field is located at a small depression along the eastern part of the Iheya Ridge where basalt breccia occurs (Fig. 27.7). In 1988, the Clam Site was the second discovery of high temperature hydrothermal activity in the Okinawa Trough. A deep-tow TV camera survey at this site revealed the presence of a clam colony. Intensely hydrothermally altered and sometimes consolidated sediment was recognized in a small area $(100 \times 50 \mathrm{~m})$ at a water depth of 1,392 $\mathrm{m}$ (Nakashima et al. 1995). In some areas, forests of small chimneys (less than $10 \mathrm{~cm}$ in height) were recognized along the fissure, where calm diffusive emanations of clear fluids occur. The landmark feature of 

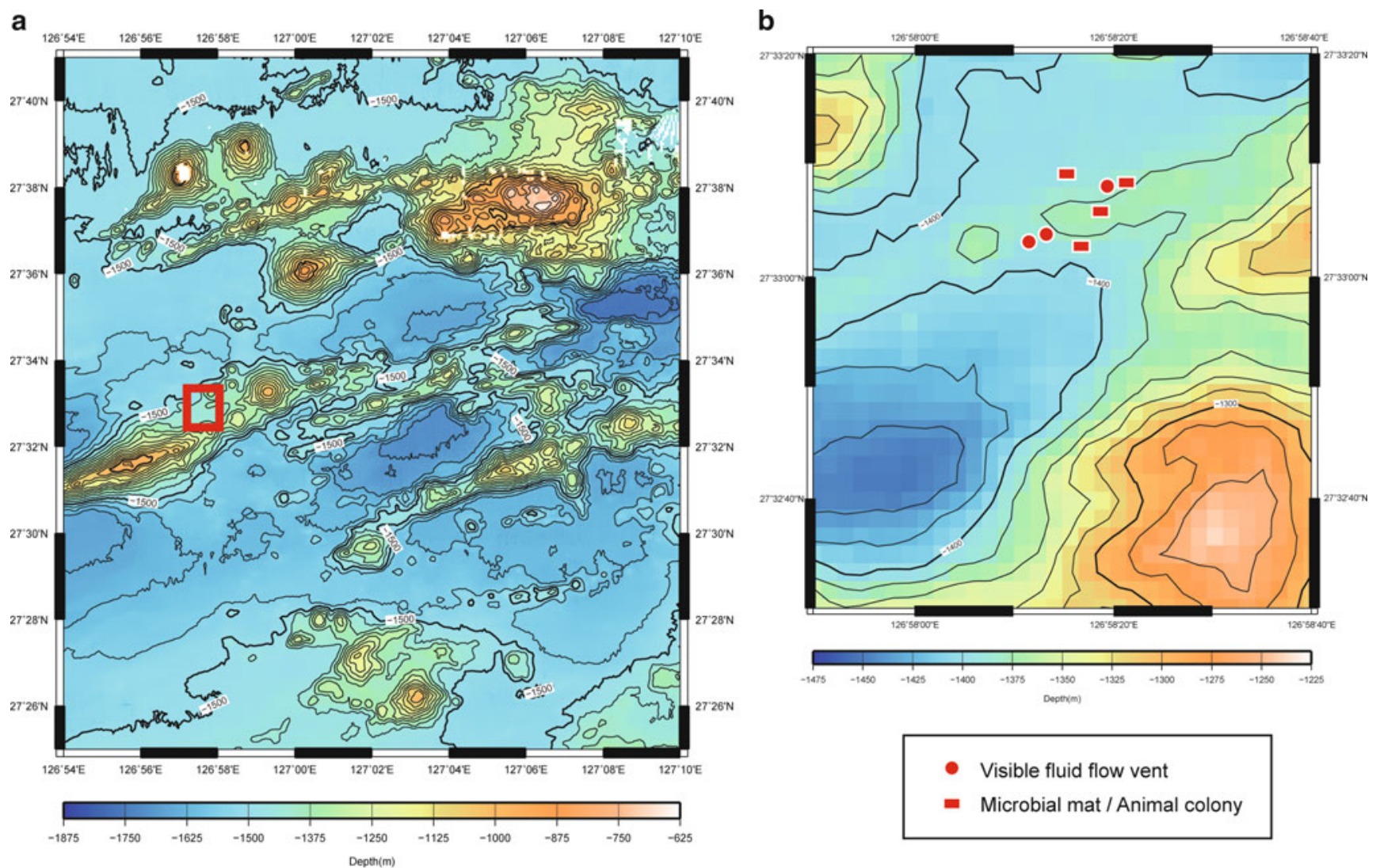

Fig. 27.7 (a) Topography of the Iheya Ridge (b) Localities of active fluid venting in the Clam hydrothermal field. Note that map (a) is not the same scale as other figures

the Clam hydrothermal field, $2 \mathrm{~m}$ high cone-shaped chimney structure called the Pyramid chimney discharged hydrothermal fluid from the foot part of the structure. The fluid temperature fluctuated year to year of sampling, and the highest temperature was recorded as $220{ }^{\circ} \mathrm{C}$ in 1988 . Venting was ceased in 1990, and since then, dive studies have not been conducted in this field.

Mineralization in the Clam field was characterized by carbonate precipitates (Nakashima et al. 1995). The carbonates collected from the chimney structure consisted of manganoan calcite, rhodochrosite, anhydrite, and amorphous silica, with only trace amounts of sulfides including wurtzite, pyrrhotite, chalcopyrite, isocubanite and realgar present as disseminations (Izawa et al. 1991). Native sulfur was also recovered from the outer region of the field. Carbonates precipitation should be related to high alkalinity of the hydrothermal fluid, which is accompanied with increase of ammonium ion and ${ }^{34} \mathrm{~S}$-enriched sulfate (Gamo et al. 1991). As they demonstrated, this fluid chemistry would be attributed to be affected by sulfate reduction utilizing supplied hydrothermal methane and/or organic matter decomposition in the sediment layer, which in turn induces carbonate mineralization. This idea is supported by microscopic observations where replacement of anhydrite and gypsum by carbonate or sulfide minerals was recognized by the crystal texture (Nakashima et al. 1995).

At the summit area of the Natsushima 84-1 knoll (water depth of $1,540 \mathrm{~m}$ ), which is located about $15 \mathrm{~km}$ east extension of the Iheya Ridge, low-temperature hydrothermal activity was first discovered in 1986 in the middle Okinawa Trough (Kimura et al. 1988). Shimmering water from one of the mounds has a temperature $2-3{ }^{\circ} \mathrm{C}$ higher than that of the ambient seawater, while methane and manganese anomalies were detected. The mound was covered with a yellowish brown deposit of Fe-rich smectite and Fe-Mn oxyhydroxide (Masuda et al. 1987).

\subsubsection{Iheya North Knoll Hydrothermal Field}

The Iheya North Knoll hydrothermal field is located along the eastern slope (at water depth about 1,000 m) of a small knoll which constitutes a volcanic complex of the Iheya North Knoll (Fig. 27.8). Seismic studies around the Iheya North Koll demonstrated relatively disordered seismic reflectors as deep as 400-500 mbsf (meters below the 

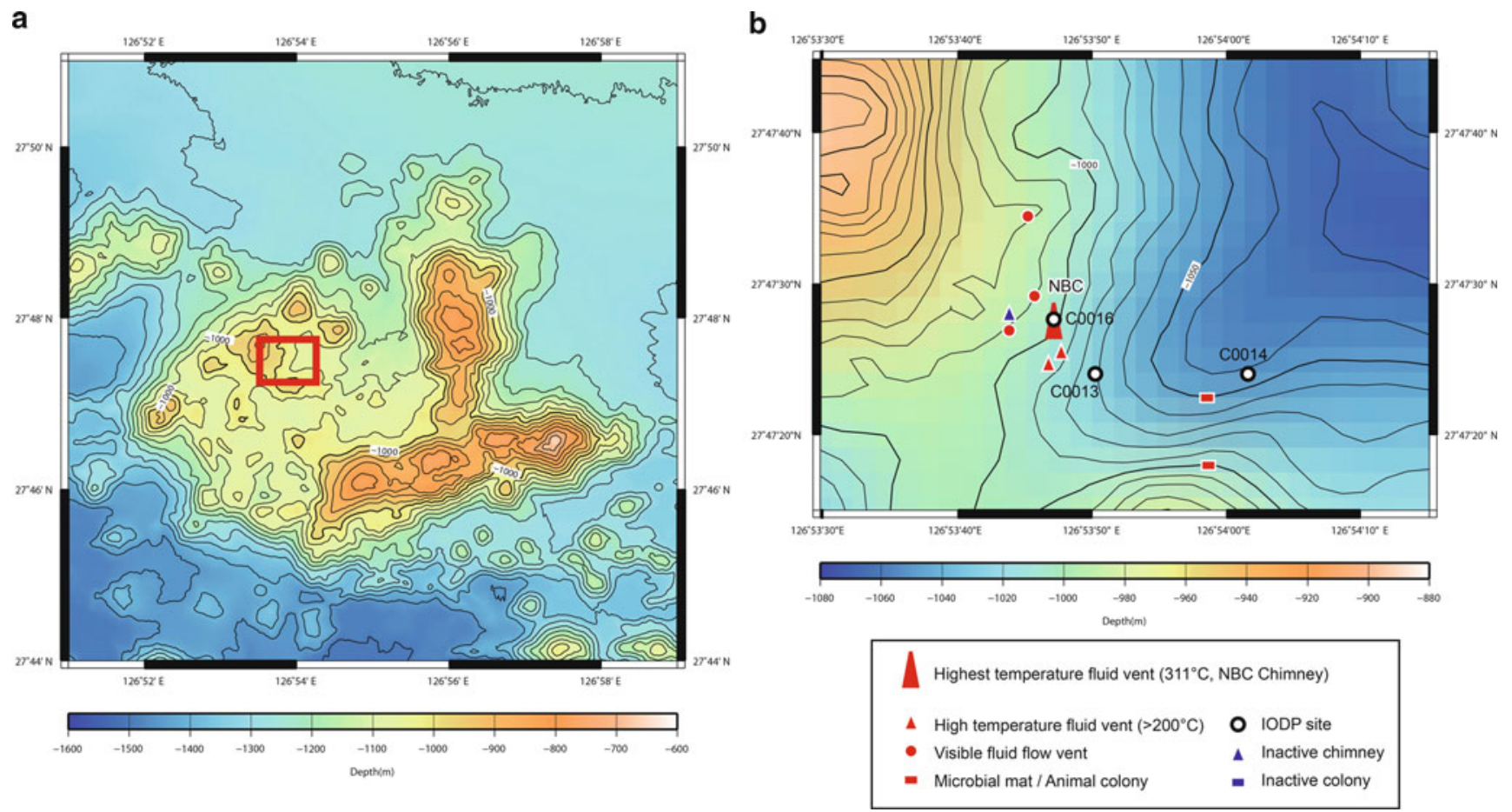

Fig. 27.8 (a) Topography of the Iheya North Knoll (b) Localities of active fluid venting in the Iheya North Knoll hydrothermal field

seafloor) in the Central Valley that were surrounded by small knolls (Tsuji et al. 2012). This suggested presence of pumiceous volcaniclastic flow deposits below surficial hemipelagic sediments, rather than massive igneous rocks. Indeed, previous geological studies using gravity cores have recovered a large volume of pumiceous volcaniclastic sediment in the Central Valley.

About ten of the active hydrothermal mounds are concentrated in a small region, aligned north to south. Many of the mounds host active fluid venting and sulfide/ sulfate mineralization. A large mound of more than $30 \mathrm{~m}$ height associated with vigorous venting of clear fluid with the highest temperature of $311^{\circ} \mathrm{C}$ (called NBC (North Big Chimney) mound) appears to mark a center of the hydrothermal activity at the Iheya North Knoll (Nakagawa et al. 2005). A diversity of fluid chemistry and temperature within the hydrothermal field has been attributed to subseafloor phase separation (Kawagucci et al. 2011).

Mineralization in the Iheya North Knoll was studied based on analysis of active and inactive chimneys collected from the seafloor (Ueno et al. 2003). Main sulfide minerals are sphalerite, wurtzite, galena, pyrite, marcasite, chalcopyrite and tennantite-tetrahedrite. Luzonite and freieslebenite and covellite were identified in a few samples. Gangue sulfates consist mainly of barite, gypsum and anhydrite.

During scientific drilling by IODP Expedition 331, a variety of hydrothermal sulfide/sulfate deposits were successfully recovered from below the seafloor (Takai et al.
2011, 2012; Yeats et al. 2012; Ishibashi et al. 2013). Blocks of massive sphalerite-(pyrite-chalcopyrite)-rich sulfides, coarsely crystalline anhydrite aggregate and silicified rocks disseminated with veins contained pyrite were identified in the core drilled at the flank of the NBC (North Big Chimney) hydrothermal mound. Sulfide mineralization was identified also within intensively altered sediment at two drilled sites, 100 and $450 \mathrm{~m}$ east of the NBC mound. Occurrence of sulfides in the upper portions was characterized by detrital grains which included euhedral fragments of sphalerite and pyrite. In the core at greater depths, quartz-sulfide veins were present among silicified volcanic breccia, some of which contained chalcopyrite, sphalerite and galena.

\subsubsection{Yoron Hole Hydrothermal Field}

The Yoron Hole hydrothermal field is located on the northeastern slope of a small depression termed as the Yoron Hole (Fig. 27.9). This caldera-like depression approximately $3 \mathrm{~km}$ in a diameter was recently identified by detailed mapping (Horisako et al. 2010). Hydrothermal activity was only observed at two small areas at water depths of 560-590 m (Fukuba et al., Chap. 38). All of the active smokers discharged clear fluid, with the highest temperature of $247^{\circ} \mathrm{C}$.

Active chimney samples collected from the Yoron Hole hydrothermal field consisted of dominantly barite associated 

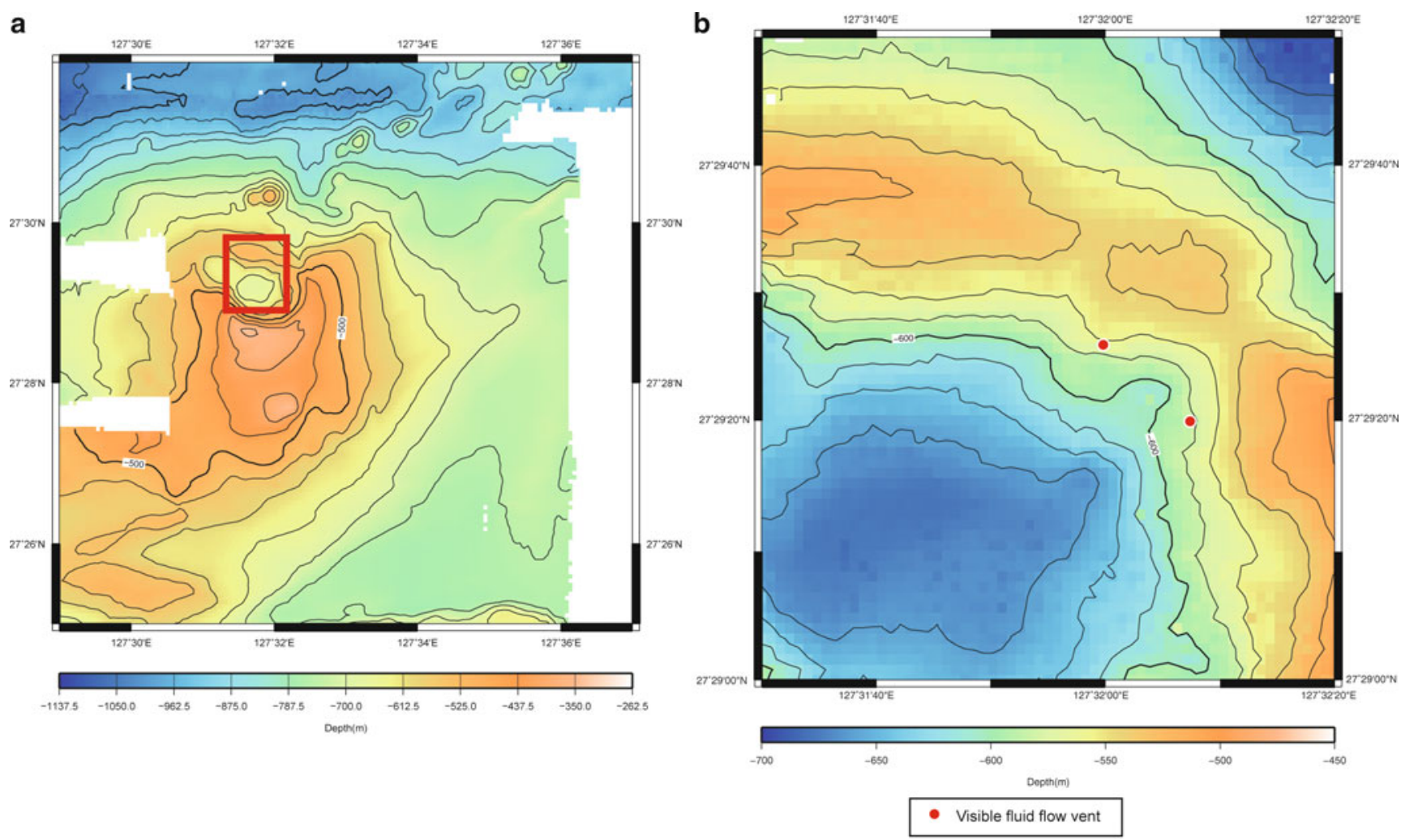

Fig. 27.9 (a) Topography of the Yoron Hole (b) Localities of active fluid venting in the Yoron Hole hydrothermal field

with sulfide minerals of sphalerite, galena pyrite tetrahedrite-tennantite or associated with combination of stibnite, orpiment and $\mathrm{Pb}-\mathrm{Ag}$-Sb sulfide (Ooki et al. 2012). The latter mineral assemblage could be attributed to low temperature mineralization. Massive sulfide was recognized only at one site, which mineral association was composed of dominant sphalerite and pyrite, minor chalcopyrite, stibnite, covellite and tetrahedrite-tennantite.

\subsubsection{Minami-Ensei Knoll Hydrothermal Fields}

The Minami-Ensei Knoll hydrothermal field is located in one of small depressions (named as $\mathrm{C}$ depression) of the Minami-Ensei Knoll (Fig. 27.10). This knoll is characterized by complicated topography which includes small hills and depressions within a circular rim of $2 \mathrm{~km}$ radius. Poorly vesciculated pumice, diorite, and granite samples were recovered from this knoll implying the knoll is a volcanic complex. The "C depression" of $300 \times 100 \mathrm{~m}$ in size is located on the western slope of the knoll at a water depth of $\sim 700 \mathrm{~m}$. Several rather small chimneys were recognized as aligned along an $\mathrm{N}-\mathrm{S}$ direction. Many of them discharged transparent fluids with the highest temperature of $278{ }^{\circ} \mathrm{C}$ (Chiba et al. 1993).
According to Nakashima et al. (1995), mineralization in the Minami-Ensei Knoll field can be classified into four types; (i) anhydrite-rich chimneys, immature precipitates of anhydrite and/or gypsum including sulfide disseminations consisting of chalcopyrite, sphalerite, pyrite, galena, anglesite; (ii) massive $\mathrm{Zn}-\mathrm{Pb}-\mathrm{Cu}$ sulfides, consisting of pyrite, sphalerite, galena and chalcopyrite; (iii) clastic layers consist of both volcanic and hydrothermal particles. Volcanic material is mainly pumiceous fragments which were filled up with sulfide minerals including sphalerite, pyrite, chalcopyrite, galena, tetrahedrite-tennantite, realgar, and stibnite. All of the active chimneys are fragile anhydrite or gypsum chimney, and massive or sheeted sulfide are collected only from the seafloor.

\subsubsection{Hydrothermal Mineralization in the North Okinawa Trough}

The northern Okinawa Trough had been long considered be devoid of active volcanism (e.g. Kimura 1996), while the volcanic front is obviously recognized as a series of the Tokara volcanic islands. Yokose et al. (2010) proposed that this volcanic chain extends in a southwest direction to submarine knolls along the North Okinawa Trough, based on 
a

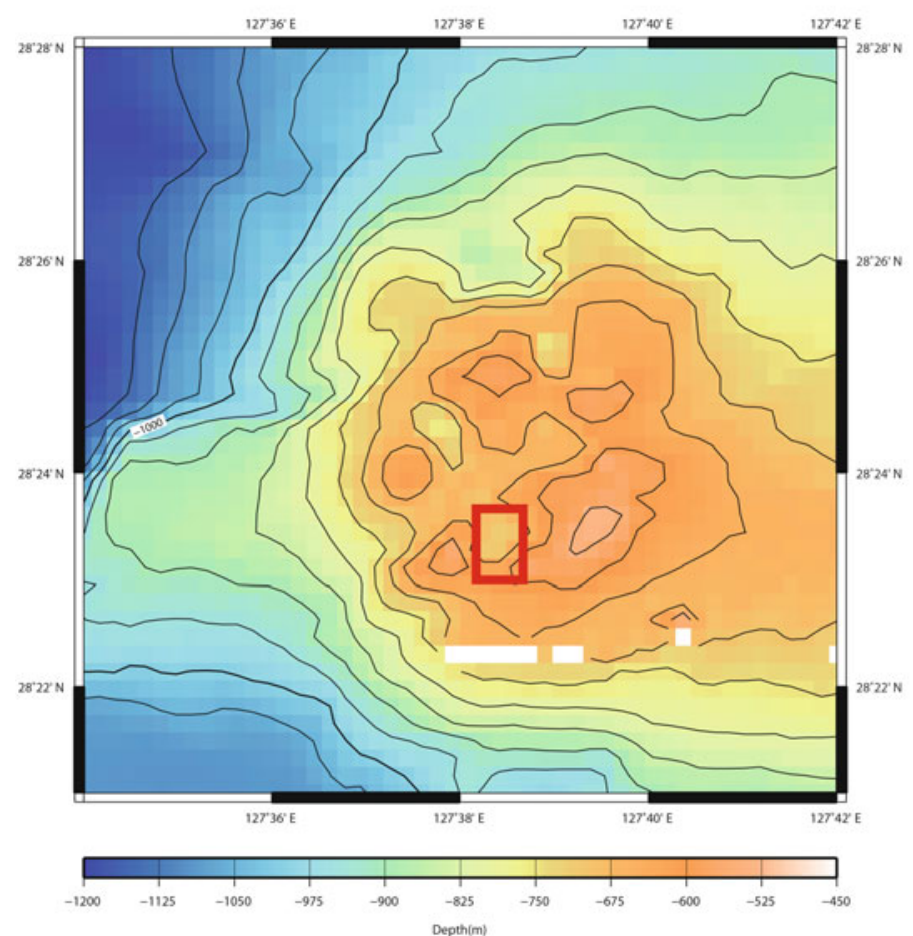

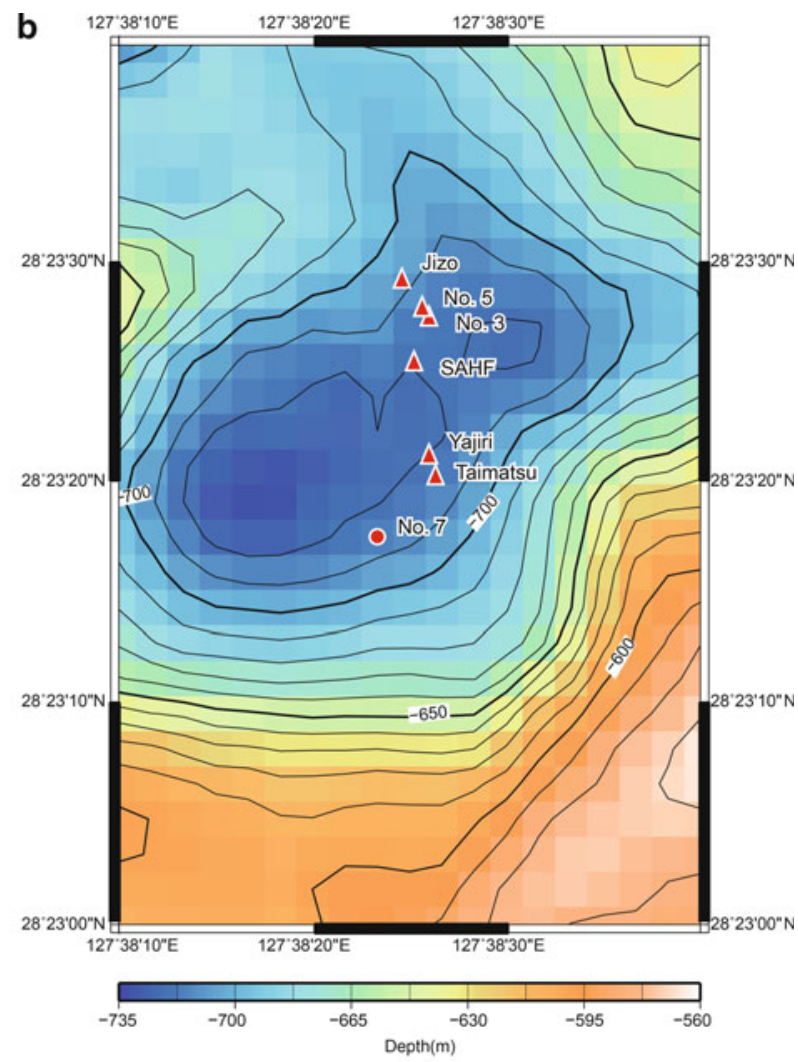

A High temperature fluid vent $\left(>200^{\circ} \mathrm{C}\right) \neq$ Sulfur crust

- Visible fluid flow vent

Inactive chimney

- Microbial mat / Animal colony
- Inactive colony

Fig. 27.10 (a) Topography of the Minami-Ensei Knoll (b) Localities of active fluid venting in the Minami-Ensei Knoll hydrothermal field

petrologic study together with detailed mapping. They also recognized some submarine caldera structures in the volcano chain, from where subangular to angular cobble-boulder fragments of lava, scoria and pumice of volcanic rocks were abundantly recovered by dredging. As mineralized samples, Fe-Mn oxide crusts enriched in As and Mo were documented as dredged from the Amami caldera, one of the submarine calderas (Yokose et al. 2009). The northern Okinawa Trough has become one of target regions for recent exploration of seafloor hydrothermal deposits.

\subsection{Characteristics of Hydrothermal Mineralization in the Okinawa Trough}

\subsubsection{Chemical Signature of Hydrothermal Ores}

As described in the previous section, a diverse range of mineralization has been recognized in most of the hydrothermal fields in the Okinawa Trough. For sulfide mineralization, sphalerite and galena are the principal minerals in most of the fields. Pyrite, chalcopyrite, marcasite, and/or tetrahedrite-tennantite are also commonly identified. Sulfates such as anhydrite, gypsum and barite are also recognized abundantly in all the fields. On the other hand, carbonate has only been recognized in two fields, the Daiyon-Yonaguni Knoll and Clam field.

To confirm this common signature, bulk chemical composition of mineralized samples collected from the hydrothermal fields in the Okinawa Trough is compiled in Fig. 27.11. A plus symbol in the figure indicates an average grade of 392 drilled core samples from the Hakurei field (METI 2013); which was reported as $\mathrm{Cu}=0.51 \mathrm{wt} \%, \mathrm{~Pb}$ $=3.49 \mathrm{wt} \%, \mathrm{Zn}=9.69 \mathrm{wt} \%, \mathrm{Fe}=30.68 \mathrm{wt} \%, \mathrm{Au}=3.2$ $\mathrm{g} / \mathrm{t}$ and $\mathrm{Ag}=250 \mathrm{~g} / \mathrm{t}$. The data plot is likely to be shifted to Fe-rich; however this is mainly because a significant amount of pyrite in the alteration zone was included. Sulfide ores from the Okinawa Trough are notably enriched with $\mathrm{Zn}$ and $\mathrm{Pb}$ compared with sulfide samples collected from seafloor hydrothermal fields in the mid-ocean ridge setting. As several researchers have pointed out, above signatures of mineralization found in the Okinawa Trough is similar to that of Kuroko-type deposits which are usually polymetallic 


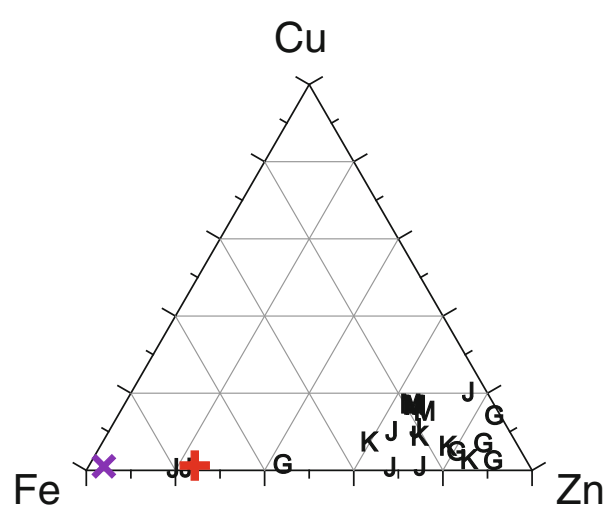

Fig. 27.11 Ternary diagrams for major chemical composition of hydrothermal ore samples collected from the hydrothermal fields in the Okinawa Trough. A red cross mark plots an averaged value of 392 drilled core samples from the Hakurei field (METI 2013). A purple cross mark plots an averaged value of drilled cores obtained from the Bent Hill massive sulfide deposit in the Middle Valley of the Juan de

( $\mathrm{Zn}-\mathrm{Pb}-\mathrm{Cu}-\mathrm{Ag}-\mathrm{Au}$, with trace metal associations). It is notable that the common signature in the bulk chemical composition is recognized in spite of a diverse range of a water depth and geologic setting where the hydrothermal activity is hosted. This signature can be attributed to reflect the chemical signature of the ore fluid which transports metals. It is reasonable to expect enrichment in $\mathrm{Pb}$ in the hydrothermal ores from the Okinawa Trough, compared with those from the mid-ocean ridge setting, as both island arc magma and surrounding continental crust are enriched in $\mathrm{Pb}$ (e.g. Halbach et al. 1997).

Enrichment in some specific trace elements such as As, $\mathrm{Sb}$ and $\mathrm{Ag}$ has been noticed in sulfide ores from the Okinawa Trough both by geochemical studies (e.g., Noguchi et al. 2007) and mineralogical studies (e.g., Halbach et al. 1989). Sulfide minerals of these elements have been considered as precipitated in the later low-temperature stages based on their occurrence often found in the outer part of the ores (Halbach et al. 1989). Enrichment in these elements is observed also in the Kuroko-type deposits, but not so much considerable (Glasby et al. 2008). However, this difference has not been well discussed.

\subsubsection{Style of Mineralization Below the Active Hydrothermal Field}

Although several studies have described the characteristics of hydrothermal mineralization at sites across the Okinawa Trough, most of them were based on analytical results of mineralized samples collected from above the seafloor using a submersible or dredge. This situation is quite different from that our knowledge about Kuroko-type deposits has been accumulated by studying numerous core samples drilled for

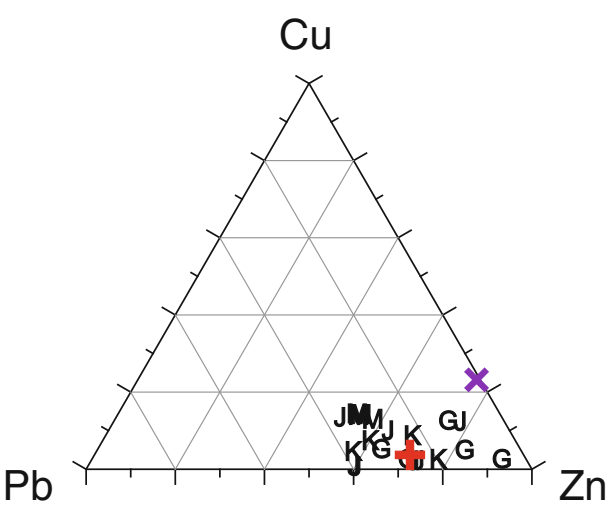

Fuca Ridge during ODP Leg 169 (Lawrie and Miller 2000). Alphabetical symbols represent a name of a hydrothermal field where samples were collected, G: Daiyon-Yonaguni Knoll field (Suzuki et al. 2008), $M$ : Hatoma Knoll field (Okamoto et al. 2002), $J$ : Jade site in the Izena Hole (Halbach et al. 1993), K: Iheya North Knoll field (Ueno et al. 2003)

underground exploration. Because the stratabound mineralization is one of important characteristics for the Kuroko-type deposits, our present understanding of mineralization in the Okinawa Trough might be distorted due to the sampling bias. Deep drilling during IODP Expedition 331 provided the first opportunity to overcome this problem by revealing the subseafloor hydrothermal structure at the Iheya North Knoll (Takai et al. 2012).

Lithologies at the Iheya North Knoll field are characterized by a complex mixed sequence of coarse pumiceous volcaniclastic and fine hemipelagic sediments, overlying dacitic to rhyolitic volcanic substrate (Yeats et al. 2012). Together with the seismic image obtained by previous investigation (Tsuji et al. 2012), these lithologies are likely to be horizontally continuous between the drilled sites up to $1 \mathrm{~km}$ (Takai et al. 2012). Sulfide occurrences are shown in a compilation of vertical profiles at two drilled sites; C0013 located at $100 \mathrm{~m}$ east of the central mound and $\mathrm{C} 0014$ at $450 \mathrm{~m}$ east, in Fig. 27.12a. Sulfide mineralization at these two sites was characterized by the occurrence of detrital grains which included euhedral crystals of sphalerite and pyrite in the upper portions of sediment, $0-12$ mbsf at $\mathrm{C} 0013$ and $0-19$ mbsf at C0014 (Takai et al. 2012; Ishibashi et al. 2013). Sediment in some sections collected from Site C0013E was heavily mineralized, with layers up to $10 \mathrm{~cm}$ in thickness probably exceeding $50 \%$ total sulfide, while the sulfidic grits were relatively scarce at Site C0014. In the core at greater depths (26-28 mbsf at C0013 and, 109-113 mbsf and 127 mbsf at C0014), quartz-sulfide veins among silicified volcanic breccia were present; some of them contained chalcopyrite, sphalerite and galena. Sulfate minerals, anhydrite and/or gypsum were abundant in the intermediate layer (6-24 mbsf at C0013 and 57-100 mbsf at C0014), sometimes breccia with euhedral anhydrite clasts were noted. 


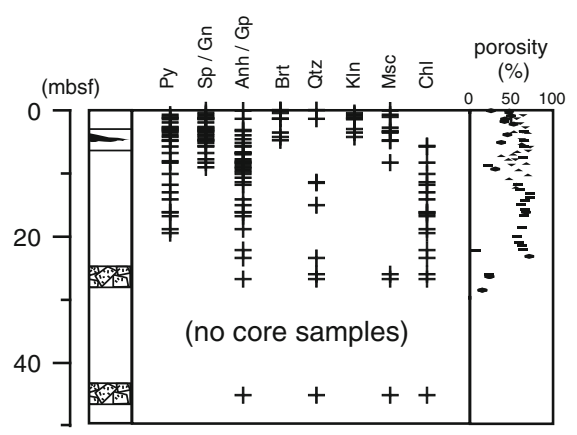

$\rightleftharpoons$ Sulfidic grit

Quartz-pyrite vein
C0014 (450 m east of the mound)

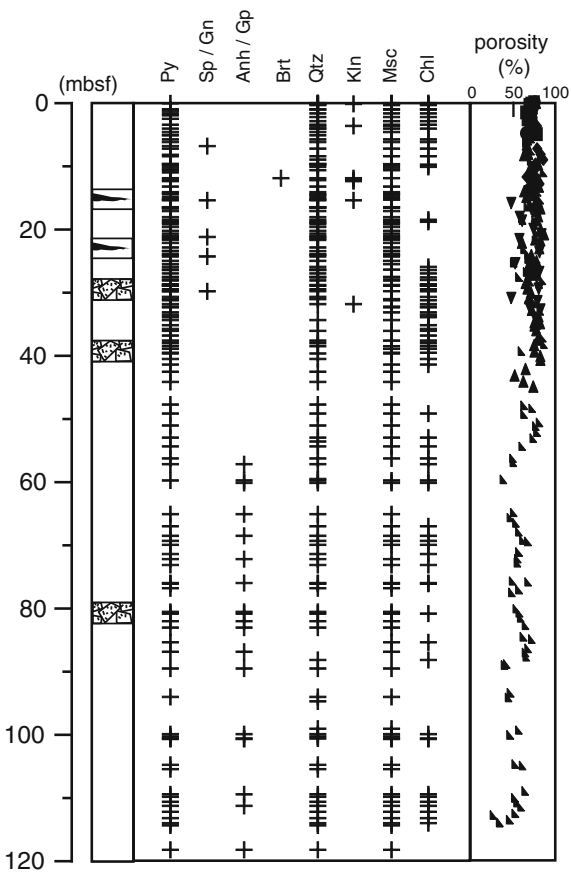

b

No. 7 ore body of Shakanai mine

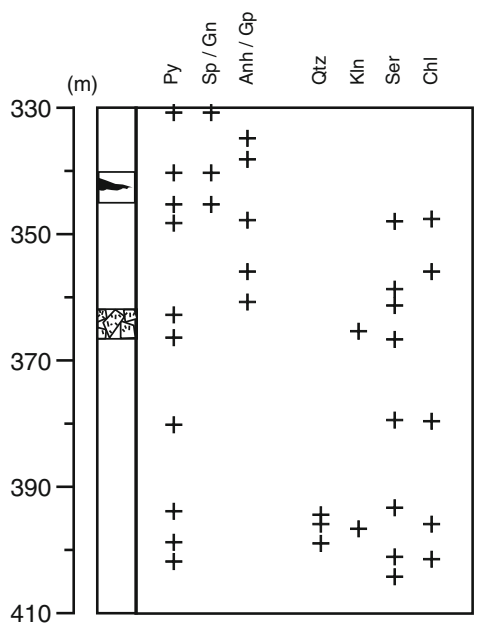

Fig. 27.12 Comparison of occurrence of dominant sulfide, sulfate and clay minerals between (a) cores obtained from Sites C0013 and C0014 on the Iheya North Knoll during IODP Expedition 331, based on results of onboard XRD analysis (Takai et al. 2011), and (b) cores obtained from the No. 161 borehole that penetrated the No.7 ore body of the Shakanai mine, a typical Kuroko-type deposit in northeast Japan (modified after Iijima 1974). In Fig. 27.12a, profiles of porosity of the core samples determined by onboard physical property measurements are shown together (Takai et al. 2011). In Fig. 27.12b, a depth of $330 \mathrm{~m}$ corresponded to the top of the Shakanai Formation of Nishikurosawa Stage in middle Miocene. Abbreviation for mineral names: Py pyrite, $S p / G n$ sphalerite and/or galena, $A n h / G p$ anhydrite and/or gypsum, Brt barite, Qtz quratz, Kln kaolinite, Ms muscovite, Chl chlorite, Ser sericite (mainly muscovite)
By drilling into the flank part of the active hydrothermal mound (NBC mound) at Site C0016, a variety of mineralization styles were successfully recovered (Takai et al. 2011; Yeats et al. 2012). Blocks of massive and semi massive sulfide were obtained from the first core (0-9 mbsf). Underlying recovered lithologies included snow-white, coarsely crystalline anhydrite aggregate with a dark vein of pyrite (9-27 mbsf), along with silicified and variably altered volcanic rocks. Shipboard work by Yeats et al. (2012) demonstrated that recovered massive sulfides show clear evidence for formation by both surface detrital and subsurface chemical processes, with some sphalerite precipitation in void spaces. Sulfide and sulfate paragenesis is consistent with an evolving system, where early sphalerite mineralization is overprinted by pyrite and then chalcopyrite as the temperature increases, prior to late sphalerite precipitation as it cools (Yeats et al. 2012). Late coarse anhydrite is consistent with final seawater influx (Yeats et al. 2012). Quartzmuscovite/illite and quartz-chlorite alteration of underlying lithologies (Takai et al. 2011; Yeats et al. 2012) are consistent with proximal hydrothermal alteration associated with Kuroko-type VMS deposits.
The vertical profiles of mineral occurrence documented for the obtained cores are directly compared to those from Kuroko-type deposits in Fig. 27.12b. A typical Kuroko-type VMS deposit, according to the classic study by Sato (1974), is usually composed of gypsum ore, siliceous ore, yellow ore, black ore, barite ore and ferruginous chert ore in stratigraphically ascending order. As well as the sphaleriterich massive sulfides, the sulfidic grits in the upper portion sediment could correspond to "black ore". The siliceous volcanic breccia with sulfide veins may correspond to the "siliceous ore". Material reminiscent of Kuroko-type "yellow ore" was not identified in the cores. The interval of thick hydrothermal alteration with abundant anhydrite may be corresponded to the "gypsum ore", but may also represent seawater influx into the system. The agreement in the 2-D structure both in vertical and horizontal scale supports the idea that mineralization recognized at the Iheya North Knoll is associated with a hydrothermal system similar to that formed Kuroko-type VMS deposits.

Another important success during the IODP drilling was recovery of the sphalerite-rich massive sulfide blocks that strongly resemble the "black ore" of Kuroko-type deposits 
(Yeats et al. 2012). Clastic textures comprising fragments of hydrothermal clay and siliceous volcanic material were recognized by microscopic observation, which is attributed to be formed by subsurface chemical processes involving surface detrital material. On the other hand, chimneys collected from active or inactive vents on the seafloor often showed distinctive mineral texture that is explained by a result of precipitations during quench process, such as colloforms mainly consists of pyrite, dendritic growth texture, and also by small grain size (Ueno et al. 2003). These textures have been rarely recognized in Kuroko-type deposits, as demonstrated by Shikazono and Kusakabe (1999). It is notable that the mineralization observed in the drilled cores collected from 100 to $450 \mathrm{~m}$ apart from the hydrothermal mound is characterized by occurrence of sulfidic detrital grains. By microscopic observation, euhedral crystals of sphalerite and pyrite were identified as closely associated with abundant clay minerals (Ishibashi et al. 2013). This texture is also quite distinctive from the texture recognized in chimneys collected from active or inactive vents.

\subsubsection{Diverse Range of Mineralization and Fluid Chemistry}

Active hydrothermal fields in the Okinawa Trough are located in rather shallow water depth from 700 to $1,600 \mathrm{~m}$. Moreover, the highest temperatures of venting fluids are close to the boiling temperature of the seawater at pressure corresponding to the water depth of the seafloor in many fields. Geochemical studies of venting fluids indicated evidence for subseafloor phase separation in several hydrothermal fields in the Okinawa Trough (Kawagucci, Chap. 30). Evidence for subseafloor phase separation was also recognized by a systematic study of fluid inclusions in the Jade field (Lüders et al. 2001, 2002). As several previous studies pointed out that phase separation should play important roles in mineralization process, because it causes drastic change in fluid chemistry (e.g. Drummond and Ohmoto 1985).

As described in the Sect. 27.3.1, the relationship between a diverse range of mineralization styles and intra-field variation of fluid chemistry was recognized in the Daiyon-Yonaguni Knoll hydrothermal field, and attributed to influence of subseafloor phase separation (Suzuki et al. 2008). Sulfide mineralization was dominantly observed in chimney-mound structures in the proximal area where vigorous venting of high temperature and slightly $\mathrm{Cl}$-enriched fluid are concentrated. Carbonate mineralization was found in the distal area where Cl-depleted and transparent fluid venting sometimes associated with discharge of $\mathrm{CO}_{2}$ liquid droplets was observed. Similar intra-field diversity in fluid chemistry was recognized also in the Jade field (Ishibashi et al. 2014). Such a geographical distribution of hydrothermal discharge is similar to the diversity of fluid discharges observed in a subaerial geothermal field. As Giggenbach et al. (1994) documented for a geothermal field in New Zealand, high-temperature Na$\mathrm{Cl}$ type springs from the brine phase are located in the central area and acid-sulfate type springs originated from the vapor phase are located in the peripheral area in many cases. Since the phase separation of the hydrothermal fluids in the Okinawa Trough occurs in the sub-critical condition, hydrological behavior of two phases should be similar to the case of boiling occurs in an on land geothermal system rather than that of super-critical phase separation in the deep region (e.g. in the vicinity of a magma body).

Venting of hydrothermal fluids experienced boiling (phase separation in the sub-critical condition) has been documented by several studies (e.g. Butterfield et al. 1990; Takai et al. 2008). They demonstrated diversity of observed fluid chemistry is almost quantitatively explained by participation of chemical species during the subseafloor boiling; gas species such as $\mathrm{CO}_{2}$ and $\mathrm{H}_{2} \mathrm{~S}$ into the vapor phase, while ion species such as $\mathrm{Cl}$ and $\mathrm{Na}$ into the liquid phase. They also mentioned that hydrothermal fluid in natural systems discharges from the seafloor before physical segregation of vapor and liquid phases completes, because phase separation usually occurs during rapid fluid ascending. In the DaiyonYonaguni Knoll hydrothermal system, the high temperature $\mathrm{Cl}$-enriched hydrothermal fluids are interpreted as the mainstream of the ascending fluid which has experienced vapor loss during the boiling, while Cl-depleted hydrothermal fluids are condensate of the vapor-rich phase which has branched (Suzuki et al. 2008).

Participation of ore-forming elements during phase separation (both in subcritical and supercritical conditions) was discussed in detail in a review by Heinrich (2007). Elements which forms chloride-complex such as $\mathrm{Na}, \mathrm{Fe}, \mathrm{Zn}, \mathrm{Pb}$ partition more into the liquid phase, basically in proportion to $\mathrm{Cl}$ enrichment (Pokrovski et al. 2005). Behavior of $\mathrm{Cu}$ is unique; $\mathrm{Cu}$ follows the same trend as $\mathrm{Zn}$ under $\mathrm{S}$-free condition, while addition of $\mathrm{S}$ into the system as an additional complexing ligand causes enrichment in $\mathrm{Cu}$ in favor of the vapor phase (Nagaseki and Hayashi 2008). Hydroxycomplexed elements including $\mathrm{As}, \mathrm{Sb}$ and $\mathrm{Au}$ reach relatively higher concentrations in the vapor phase. These results indicate fractionation between vapor and liquid phases is highly element-specific, suggesting phase separation can be an important step in the segregation of elements to form certain types of ore deposits (Heinrich 2007). In natural systems, also drastic $\mathrm{pH}$ change should associate with phase separation due to favorable participation of gas species in the vapor phase (Drummond and Ohmoto 1985). Because the solubility of metal elements is substantially controlled by fluid $\mathrm{pH}$, this effect makes the behavior of metals during phase separation more complex. Irrespective 
of such complex behaviors, the sulfide mineralization associated with vigorous venting of high temperature and slightly $\mathrm{Cl}$-enriched fluid in the Daiyon-Yonaguni field is reasonable, because influence of phase segregation would be limited based on the observed $\mathrm{Cl}$ concentration slightly higher than the seawater (Suzuki et al. 2008).

On the other hand, it is notable that only Cl-depleted hydrothermal fluid was recognized in the Hatoma Knoll and Minami-Ensei Knoll hydrothermal fields. All the active chimneys in these two fields are anhydrite dominant sulfate chimney, in which sulfide minerals are identified only as disseminated. Exclusive anhydrite mineralization observed in the entire hydrothermal field could be explained by less participation of metals into the vapor phase during the subseafloor phase separation, although cooling of the ascending hydrothermal fluid should be another important factor which induces low solubility of metal elements, especially for $\mathrm{Cu}$. Similar significant metal loss associated with fluid phase separation was documented for a subaerial but seawater-dominated geothermal system in Iceland (Hardartóttir et al. 2009). While hydrothermal fluids collected from in situ wells at 1,350-1,500 m depth contained sub-millimolar order of $\mathrm{Fe}, \mathrm{Cu}$ and $\mathrm{Zn}$, samples collected at the surface of the same wells had orders of magnitude lower metal concentrations. This significant difference was attributed to precipitation caused by boiling during depressurization, which was confirmed by occurrence of $\mathrm{Cu}$-rich scales deposit at the orifice of the well (Hardartóttir et al. 2010). Based on this result, they proposed that subseafloor mineralization associated with phase separation may occur in some submarine hydrothermal systems where boiling of fluids occur before discharging from seafloor vents. If it is the case applicable to the hydrothermal fields in the Okinawa Trough, subseafloor mineralization could be one of important processes for formation of VMS deposits. This idea may be supported by an observation of post-drilling changes after IODP Expedition 331 (Kawagucci et al. 2013), which documented rapid growth of sulfide-sulfate chimney structure on the artificial vent drilled as Hole C0016A into the NBC mound (Nozaki et al. 2013). They reported occurrence of sulfide minerals (mainly composed of chalcopyrite, sphalerite, and galena) inside of the newly grown chimney associated with venting of $\mathrm{Cl}$-enriched hydrothermal fluid after drilling, while only a small anhydrite chimney had been observed as active vents on the NBC mound associated with Cl-depleted fluid emanation.

The diverse range of mineralization in the hydrothermal fields in the Okinawa Trough is also recognized in a compilation of the FeS content in sphalerite/wurtzite (Fig. 27.13). Many of collected samples show significant low FeS content in $\mathrm{ZnS}$ less than $5 \mathrm{~mol} \%$. On the other hand, higher $\mathrm{FeS}$ content in $\mathrm{ZnS}$ than $10 \mathrm{~mol} \%$ was recognized in the samples collected from the Daiyon-Yonaguni and Jade field, where
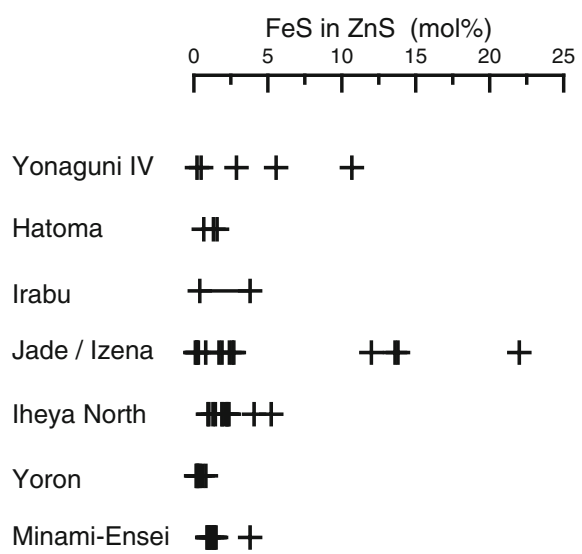

Fig. 27.13 Comparison of FeS content in sphalerite/wurzite (mol\%) for samples collected from the Okinawa Trough. Data sources are as bellows; Daiyon-Yonaguni Knoll field (Suzuki et al. 2008), Hatoma Knoll field (Nakano et al. 2008), Irabu Knoll field (Watanabe et al. 2006), Jade field in the Izena Hole (Halbach et al. 1993), Iheya North Knoll field (Ueno et al. 2003), Yoron Hole and Minami-Ensei Knoll fields (Ooki et al. 2012)

brine-rich hydrothermal fluid venting was observed on the seafloor. In these samples, the high FeS sphalerite was associated with sulfide minerals formed under reductive environment such as pyrrohtite. These two groups are likely to correspond to mineralization under $\mathrm{Cl}$-depleted (gas-rich) and $\mathrm{Cl}$-enriched (gas-lost) hydrothermal fluids, as discussed in the previous study (Suzuki et al. 2008). However, the compiled $\mathrm{FeS} / \mathrm{ZnS}$ ratio is rather low compared with that observed in VMS deposits, which may be distorted due to the sampling bias in the seafloor studies. Previous studies on VMS deposit (e.g. McLeod and Stanton 1984) have demonstrated systematic change in FeS/ZnS in stratiform ores. Systematic sampling preferably including drilled core samples would be required to discuss geochemical environment for mineralization.

\subsubsection{Tectonic Setting Favorable for Effective Formation of Volcanogenic Massive Sulfide Deposits}

As discussed in the Sect. 27.2, the Okinawa Trough is a back-arc basin in the rifting stage. Development of hydrothermal systems would be stimulated by fault networks that act as fluid conduits and the frequent intrusion of a magma that supplies a heat source. Thick accumulations of terrigenous and/or volcanic sediment on the seafloor could be another important geological feature which favorable for ore deposit formation. The sulfide occurrence within the sediment layer revealed by IODP Expedition 331 suggests highly porous volcaniclastic materials provide sufficient space for fluid flow and mineral precipitation (Ishibashi 
et al. 2013). As shown in Fig. 27.12a, the porosity of hydrothermally altered sediment drastically decreased in the layer of anhydrite formation, but remained high in the layer of clay minerals alteration which includes the layers of sulfide mineralization. This advantage would be endorsed by comparison with mineralization found in drilled core samples obtained during previous scientific drillings. During ODP Leg 193 conducted in the Pacmanus field in the East Manus Basin, only minor mineralization was observed in fissures of dacite lava dome as vein type inlet (Binns et al. 2007). On the other hand, drilling during ODP Legs 139 and 169 conducted in the Middle Valley revealed formation of massive sulfide ore body below the seafloor in a tectonic setting of sedimented ridge where axial valley of terminated spreading ridge is covered with thick terrigenous turbidite (Zierenberg and Miller 2000; Goodfellow and Franklin 1993).

Considering these points, geological structure of a depression associated with magmatic intrusions is considered favorable for formation of massive sulfide deposits. A large size caldera volcano would provide such an environment in an island-arc setting. In the early rifting stage, a depression structure formed by graben surrounded by faulting would be alternative candidate. This idea has been proposed by several researchers, for formation of Kurokotype deposits (e.g. Ohmoto 1996). The Jade and Hakurei fields in the Izena Hole would be listed as the top of such examples, although volcanic activity in this hole has not been well studied. Some previous studies pointed out geographic distribution of hydrothermal mounds in the Izena Hole could be comparable to distribution of ore deposits in the Hokuroku Basin in the northeast Japan (e.g. Nakamura et al. 1989).

As Glasby and Notsu (2003) noted, several active hydrothermal fields have been discovered in clusters in the middle Okinawa Trough, where is called as the VAMP area (the Volcanic Arc Migration Phenomenon) by Sibuet et al. (1998) (Fig. 27.1). Although artificial bias of exploration efforts cannot be excluded as a possible reason, some ideas have been proposed for explanation. Halbach et al. (1989) noticed this area is a kind of overlapping area of two axial graben structures. Sibuet et al. (1998) emphasized subduction of the Daito Ridge extending beneath the VAMP area has induced stress at the base of the arc with the result that cracks propagated through the overlying brittle lithosphere acted as conduits for magmas with arc affinities to erupt at the seafloor (Fig. 27.1). Yokose et al. (2010) pointed out a series of a large size seafloor caldera structure in the North Okinawa Trough, as an extension of volcanoes of Kyushu Islands-Tokara islands. Although the volcanic front becomes unclear in the middle Okinawa Trough, the VAMP area would be assigned as the extension of this arc caldera chain.
A recent study discussed evolution of the geologic setting of the northeast Honshu arc from Early Eocene to Early Miocene (Yamada and Yoshida 2011). They proposed that extensive volcanism in the rifting stage from 21 to $14 \mathrm{Ma}$ which hosted formation of Kuroko-type deposits around the Hokuroku area (in its final period) is related to the back-arc spreading stage before $21 \mathrm{Ma}$ at the Yamato Basin located at several hundred $\mathrm{km}$ west, and recognized an eastward migration of volcanic activity with time (Yamada and Yoshida 2011). As discussed in the Sect. 27.2, geologic setting of the Okinawa Trough is considered as still in the rifting stage and evidence for the late stage in the rifting activity was appeared in the South Okinawa Trough. We may speculate about a forward stage when spreading of the Okinawa Trough starts from the southern end. If similar eastward migration of volcanic activity with time occurs in the Okinawa Trough, the middle Okinawa Trough might be the area where extensive volcanism in the rifting stimulates significant formation of VMS deposits.

\subsection{Summary}

Mineralization recognized in the seafloor hydrothermal systems of the Okinawa Trough have been considered analogous to the formation of ancient Kuroko-type VMS deposits. Mineralogical and geochemical compositions of polymetallic (zinc and lead enriched) sulfide assemblage is commonly recognized among the hydrothermal fields, which strongly resemble Kuroko-type deposits. On the other hand, microscopic observation revealed texture of the sulfide minerals collected from above the seafloor showed distinctive feature. Deep drilling into the Iheya North Knoll hydrothermal field during IODP Expedition 331 provided additional evidence for this analogy. Sulfide blocks of sphalerite-rich massive sulfides ("black ore") collected from a hydrothermal mound inside shows clear evidence for formation by both surface detrital and subseafloor chemical processes, with some sphalerite precipitation in void spaces. Moreover, vertical profiles of mineral occurrence revealed subseafloor hydrothermal structure directly comparable to that of Kuroko-type deposits both in horizontal and vertical scales. On the other hand, geochemical studies of hydrothermal fluid venting from the seafloor demonstrated that the recognized diverse range of sulfide and sulfate mineralization could be related to subseafloor geochemical processes such as phase separation and probably mineralization. These results highlighted importance of subseafloor processes for formation of VMS deposits. Drilling studies targeting a hydrothermal field, as well as integration of geological, geophysical and hydrological studies of background environment, would significantly promote our 
understanding of dynamic processes for formation of VMS deposits.

Acknowledgement We appreciate for crew, submersible team members, drilling operators and onboard scientists of all of the research cruises conducted in the Okinawa Trough. Especially, onboard and offshore scientists of the IODP Expedition 331 inspired the authors in several aspects. Discussion with the IGCP-502 program members, especially during the field excursion in the Hokuroku Basin in the northeast Japan provided the first author (J. Ishibashi) several important clues to understand the analogy with Kuroko-type deposits. Discussion with Ken Takai, Shinsuke Kawagucci, and Tatsuo Nozaki of SRRP, JAMSTEC was fruitful for the authors. Earlier version of the manuscript was significantly improved by constructive comments by Fernando Tornos and Steven Hollis. We gratefully acknowledge Japan Coast Guard (JCG) for permission of the use of their seismic profiles in this chapter. This study was partially supported by the "TAIGA project," which was funded by a Grant-in-Aid for Scientific Research on Innovative Areas (\#20109004) from the Ministry of Education, Culture, Sports, Science and Technology (MEXT), Japan. T. Tsuji gratefully acknowledges the support of the $\mathrm{I}^{2} \mathrm{CNER}$, sponsored by the World Premier International Research Center Initiative (WPI), MEXT, Japan.

Open Access This chapter is distributed under the terms of the Creative Commons Attribution Noncommercial License, which permits any noncommercial use, distribution, and reproduction in any medium, provided the original author(s) and source are credited.

\section{References}

Binns RA, Barriga FJAS, Miller DJ (2007) Leg 193 synthesis: anatomy of an active felsic-hosted hydrothermal system, eastern Manus Basin, Papua New Guinea. In: Barriga FJAS, Binns RA, Miller DJ, Herzig PM (eds) Proc ODP Sci Res 193: College Station, TX (Ocean Drilling Program), pp 1-17. doi:10.2973/odp.proc. sr.193.201.2007

Butterfield DA, Massoth GJ, McDuff RE, Lupton JE, Lilley MD (1990) Geochemistry of hydrothermal fluids from axial seamount hydrothermal emissions study vent field, Juan de Fuca Ridge: subseafloor boiling and subsequent fluid-rock interaction. J Geophys Res 95:12895-12921. doi:10.1029/JB095iB08p12895

Chiba H, Nakashima K, Gamo T, Ishibashi J, Tsunogai U, Sakai H (1993) Hydrothermal activity at the Minami-Ensei Knoll, Okinawa Trough: chemical characteristics of hydrothermal solutions. JAMSTEC Deepsea Res 9:271-282 (in Japanese with English abstract)

Drummond SE, Ohmoto H (1985) Chemical evolution and mineral deposition in boiling hydrothermal systems. Econ Geol 80:126-147

Fouquet Y, Von Stackelberg U, Charlou JL, Donval JP, Erzinger J, Foucher JP, Herzig P, Mühe R, Soakai S, Wiedicke M, Whitechurch H (1991) Hydrothermal activity and metallogenesis in the Lau back-arc basin. Nature 349:778-781

Gamo T, Sakai H, Kim E-S, Shitashima K, Ishibashi J (1991) High alkalinity due to sulfate reduction in the CLAM hydrothermal field, Okinawa Trough. Earth Planet Sci Lett 107:328-338

Gena K, Chiba H, Kase K, Nakashima K, Ishiyama D (2013) The tiger sulfide chimney, Yonaguni knoll IV hydrothermal field, southern Okinawa Trough, Japan: the first reported occurrence of Pt-Cu-Fe- bearing bismuthinite and Sn-bearing chalcopyrite in an active seafloor hydrothermal system. Res Geol 63:360-370

Giggenbach WF, Sheppard DS, Robinson BW, Stewart MK, Lyon GL (1994) Geochemical structure and position of the Waiotapu geothermal field, New Zealand. Geothermics 23:599-644

Glasby GP, Notsu K (2003) Submarine hydrothermal mineralization in the Okinawa Trough, SW of Japan: an overview. Ore Geol Rev 23:299-339. doi:10.1016/j.oregeorev.2003.07.001

Glasby GP, Iizasa K, Hannington M, Kubota H, Notsu K (2008) Mineralogy and composition of Kuroko deposits from northeastern Honshu and their possible modern analogues from the IzuOgasawara (Bonin) Arc south of Japan: implications for mode of formation. Ore Geol Rev 34:547-560. doi:10.1016/j.oregeorev. 2008.09.005

Goodfellow WD, Franklin JM (1993) Geology, mineralogy, and chemistry of sediment-hosted clastic massive sulfides in shallow cores, Middle Valley, northern Juan de Fuca Ridge. Econ Geol 88:2037-2068

Halbach P, Nakamura K, Wahsner M, Lange J, Sakai H, Kaselitz L, Hansen R-D, Yamano M, Post J, Prause B, Seifert R, Michaelis W, Teichmann F, Kinoshita M, Marten A, Ishibashi J, Czerwinski S, Blum N (1989) Probable modern analogue of Kuroko-type massive sulphide deposits in the Okinawa Trough back-arc basin. Nature 338:496-499. doi:10.1038/338496a0

Halbach P, Pracejus B, Märten A (1993) Geology and mineralogy of massive sulfide ores from the Central Okinawa Trough, Japan. Econ Geol 88:2210-2225

Halbach P, Hansmann W, Köppel V, Pracejus B (1997) Whole-rock and sulfide lead-isotope data from the hydrothermal JADE field in the Okinawa back-arc trough. Min Deposita 32:70-78

Hardartóttir V, Brown KL, Fridriksson T, Hedenquist JW, Hannington MD, Thorhallson S (2009) Metals in deep liquid of the Reykjanes geothermal system, southwest Iceland: implications for the composition of seafloor black smoker fluids. Geology 37:1103-1106

Hardartóttir V, Hannington MD, Hedenquist JW, Kjarsgaard I, Hoal K (2010) $\mathrm{Cu}$-rich scales in the Reykjanes geothermal system, Iceland. Econ Geol 105:1143-1155

Heinrich C (2007) Fluid-fluid interactions in magmatic-hydrothermal ore formation. Rev Min Geochem 65:363-387

Hirata N, Kinoshita H, Katao H, Baba H, Kaiho Y, Koresawa S, Ono Y, Hayashi K (1991) Report on DELP 1988 cruises in the Okinawa Trough Part 3. Crustal structure of the southern Okinawa Trough. Bull ERI Univ Tokyo 66:37-70

Horisako J, Dojun S, Tanaka K, Otonari Y, Hashimoto T (2010) Preliminary report of the bathymetric survey in the region to the northwest of Okinawa Island. Rep Hydrogr Oceanogr Res 46:87-91 (in Japanese with English abstract)

Iijima A (1974) Clay and zeolitic alteration zones surrounding kuroko deposits in the Hokuroku district, northern Akita, as submarine hydrothermal-diagenetic alteration products. Min Geol Spec Issue 6:267-289

Inagaki F, Kuypers MMM, Tsunogai U, Ishibashi J, Nakamura K, Treude T, Ohkubo S, Nakaseama M, Gena K, Chiba H, Hirayama $\mathrm{H}$, Ninoura T, Takai K, Jørgensen BB, Horikoshi K, Boetius A (2006) Microbial community in a sediment-hosted $\mathrm{CO}_{2}$ lake of the southern Okinawa Trough hydrothermal system. Proc Natl Acad Sci U S A 103:14164-14169

Iryu Y, Matsuda H, Machiyama H, Piller WE, Quinn TM, Mutti M (2006) Introductory perspective on the COREF project. Island Arc 15:393-406. doi:10.1111/j.1440-1738.2006.00537.x

Ishibashi J, Urabe T (1995) Hydrothermal activity related to arcbackarc magmatism in the western Pacific. In: Taylor B (ed) Backarc basins tectonics and magmatism. Plenum, New York, pp 451-495 
Ishibashi J, Miyoshi Y, Inoue H, Yeats C, Hollis SP, Corona JC, Bowden S, Yang SY, Southam G, Masaki Y, Hartnett H, IODP Expedition 331 Scientists (2013) Subseafloor structure of a submarine hydrothermal system within volcaniclastic sediments: a modern analogue for 'Kuroko-type' VMS deposits. In: Proceedings of the 12th Biennial SGA Meeting, 12-15 August 2013, Uppsala, Sweden, ISBN 978-91-7403-207-9, pp 542-544

Ishibashi J, Noguchi T, Toki T, Miyabe S, Yamagami S, Onishi Y, Yamanaka T, Yokoyama Y, Oomori E, Takahashi Y, Hatada K, Nakaguchi Y, Yoshizaki M, Konno U, Shibuya T, Takai K, Inagakai F, Kawagucci S (2014) Diversity of fluid geochemistry affected by processes during fluid upwelling in active hydrothermal fields in the Izena Hole, the middle Okinawa Trough back-arc basin. Geochem J 48:357-369. doi:10.2343/geochemj.2.0311

Ishihara S (ed) (1974) Geology of Kuroko deposits. Min Geol Spec Issue 6:435

Ishikawa M, Sato H, Furukawa M, Kimura M, Kato Y, Tsugaru R, Shimamura K (1991) Report on DELP 1988 cruises in the Okinawa Trough Part 6: petrology of volcanic rocks. Bull ERI Univ Tokyo 66:151-177

Iwasaki T, Shimamura H, Kanazawa T, Hirata T, Suehiro K, Urabe T (1990) Results of the 1984 Japan Germany joint seismic study on Ryukyu Arc. Chikyu Month 12(5):254-261 (in Japanese)

Izawa E, Motomura Y, Tanaka T, Kimura M (1991) Hydrothermal carbonate chimneys in the Iheya Ridge of the Okinawa Trough. JAMSTEC Deepsea Res 7:185-192 (in Japanese with English abstract)

Kato Y (1990) Geology and topography on the ridge south of the active hydrothermal deposits of the Izena Hole -the results of diving survey in 1989-. JAMSTEC Deepsea Res 6:27-31 (in Japanese with English abstract)

Kato Y, Nakamura K, Iwabuchi Y, Hashimoto J, Kaneko Y (1989) Geology and topography in the Izena Hole of the middle Okinawa Trough - the results of diving surveys in 1987 and 1988. JAMSTEC Deepsea Res 5:163-182 (in Japanese with English abstract)

Kawagucci S, Chiba H, Ishibashi J, Yamanaka T, Toki T, Muramatsu Y, Ueno Y, Makabe A, Inoue K, Yoshida N, Nakagawa S, Nunoura T, Takai K, Takahata N, Sano Y, Narita T, Teranishi G, Obata H, Gamo T (2011) Hydrothermal fluid geochemistry at the Iheya North field in the mid-Okinawa Trough: implication for origin of methane in subseafloor fluid circulation systems. Geochem J 45:109-124

Kawagucci S, Miyazaki J, Nakajima R, Nozaki T, Takaya Y, Kato Y, Shibuya T, Konno U, Nakaguchi Y, Hatada K, Hirayama H, Fujikura K, Furushima Y, Yamamoto H, Watsuji T, Ishibashi J, Takai K (2013) Post-drilling changes in fluid discharge pattern, mineral deposition, and fluid chemistry in the Iheya North hydrothermal field, Okinawa Trough. Geochem Geophys Geosyst $14: 4774-4790$

Kimura M (1985) Back-arc rifting in the Okinawa Trough. Mar Petrol Geol 2:222-240

Kimura M (1990) Genesis and formation of the Okinawa Trough, Japan. Mem Geol Soc Jap 34:77-88

Kimura M (1996) Active rift system in the Okinawa Trough and its northeastern continuation. Bull Disas Prev Res Inst Kyoto Univ 45:27-38

Kimura M (2000) Paleogeography of the Ryukyu Islands. Tropics 10 (1):5-24

Kimura M, Uyeda S, Kato Y, Yamano M, Gamo T, Sakai H, Kato S, Izawa E, Oomori T (1988) Active hydrothermal mounds in the Okinawa Trough backarc basin, Japan. Tectonophysics 145:319-324

Kimura M, Matsumoto T, Shinjo R, Nakamura M, Motoyama I, Machiyama H, Toyama G, Yagi H (2001) Meanders recognized in the southwestern part of the Okinawa Trough and its significance. JAMSTEC Deepsea Res 18:103-120
Klingelhoefer F, Lee C-S, Lin J-Y, Sibuet J-C (2009) Structure of the southernmost Okinawa Trough from reflection and wide-angle seismic data. Tectonophysics 446:281-288. doi:10.1016/j.tecto.2007.11.031

Konno U, Tsunogai U, Nakagawa F, Nakaseama M, Ishibashi J, Nunoura T, Nakamura K (2006) Liquid $\mathrm{CO}_{2}$ venting on the seafloor: Yonaguni knoll VI hydrothermal system, Okinawa Trough. Geophys Res Lett 33, L16607

Kotake Y (2000) Study on the tectonics of western Pacific region derived from GPS data analysis. Bull ERI Univ Tokyo 75:229-334

Kuroda T, Ozawa T (1996) Paleoclimatic and vegetational changes during the Pleistocene and Holocene in the Ryukyu Islands inferred from pollen assemblages. Jpn J Geogr 105:328-342

Lawrie D, Miller DJ (2000) Sulfide mineral chemistry and petrography from Bent Hill, ODP Mound, and TAG massive sulfide deposits. In: Zierenberg RA, Fouquet Y, Miller DJ, Normark WR (eds) Proc ODP Sci Res 169: College Station, TX (Ocean Drilling Program), pp 1-34

Lee C-S, Shore GG, Bebee LD, Lu RS, Hilde T (1980) Okinawa Trough: origin of a back-arc basin. Mar Geol 35:219-241

Letouzey J, Kimura M (1986) The Okinawa Trough: genesis of a backarc basin developing along a continental margin. Tectonophysics 125:209-230

Lin J-Y, Hsu S-K, Sibuet J-C (2004) Melting features along the Ryukyu slab tear, beneath the southwestern Okinawa Trough. Geophys Res Lett 31, L19697. doi:10.1029/2004GS020862

Lin J-Y, Sibuet J-C, Lee C-S, Hsu S-K, Klingelhoefer F, Auffret Y, Pelleau P, Crozon J, Lin C-H (2009) Microseismicity and faulting in the southwestern Okinawa Trough. Tectonophysics 466:268-280. doi:10.1016/j.tecto.2007.11.030

Lüders V, Niedermann S (2010) Helium isotope composition of fluid inclusions hosted in massive sulfides from modern submarine hydrothermal systems. Econ Geol 105:443-449

Lüders V, Pracejus B, Halbach P (2001) Fluid inclusion and sulfur isotope studies in probable modern analogue Kuroko-type ores from the JADE hydrothermal field (Central Okinawa Trough, Japan). Chem Geol 173:45-58

Lüders V, Banks DA, Halbach P (2002) Extreme $\mathrm{Cl} / \mathrm{Br}$ and ${ }^{37} \mathrm{Cl}$ isotope fractionation in fluids of modern submarine hydrothermal systems. Min Deposita 37:765-771

Marumo K, Hattori K (1999) Seafloor hydrothermal clay alteration at Jade in the back-arc Okinawa Trough: mineralogy, geochemistry and isotope characteristics. Geochim Cosmochim Acta 63 (18):2785-2804

Masuda H, Ishibashi J, Kato Y, Gamo T, Sakai H (1987) Oxygen isotope ratio and trace element composition of hydrothermal sediments from Okinawa Trough, collected with SHINKAI2000, dive 231. JAMSTEC Deepsea Res 3:225-231 (in Japanese with English abstract)

Matsumoto T, Kinoshita M, Nakamura M, Sibuet J-C, Lee C-S, Hsu SK, Oomori T, Shinjo R, Hashimoto Y, Hosoya S, Imamura M, Ito M, Tukuda K, Yagi H, Tatekawa K, Kagaya I, Hokakubo S, Okada T, Kimura M (2001) Volcanic and hydrothermal activities and possible "segmentation" of the axial rifting in the westernmost part of the Okinawa Trough -preliminary results from the YOKOSUKA/SHINKAI6500 Lequios Cruise. JAMSTEC Deepsea Res 19:95-107 (in Japanese with English abstract)

METI (2013) Report for the first stage of the program. Development of deep-sea mineral resources (in Japanese). http://www.meti.go.jp/ press/2013/07/20130705003/20130705003-2.pdf

Miki M (1995) Two-phase opening model for the Okinawa Trough inferred from paleomagnetic study of the Ryukyu arc. J Geophys Res 100:8169-8184. doi:10.1029/95JB00034

Murauchi S, Den N, Asano S, Hotta H, Yoshii T, Asanuma T, Hagiwara K, Ichikawa K, Sato T, Lutwig WJ, Ewing JT, Edger NT, Houtz RE 
(1968) Crustal structure of the Philippine Sea. J Geophys Res 73:3153-3171

Nagaseki H, Hayashi K (2008) Experimental study of the behavior of copper and zinc in a boiling hydrothermal system. Geology 36:27-30

Nagumo S, Kinoshita H, Kasahara J, Ouchi T, Tokuyama H, Asanuma T, Koresawa S, Akiyoshi H (1986) Report on DELP 1984 cruises in the middle Okinawa Trough Part 2: seismic structural studies. Bull ERI Univ Tokyo 61:167-202

Nakagawa S, Takai K, Inagaki F, Chiba H, Ishibashi J-I, Kataoka S, Hirayama H, Nunoura T, Horikoshi K, Sako Y (2005) Variability in microbial community and venting chemistry in a sediment-hosted backarc hydrothermal system: impacts of subseafloor phaseseparation. FEMS Microbiol Ecol 54:141-155. doi:10.1016/j.femsec.2005.03.007

Nakamura K, Kato Y, Kimura M, Ando M, Kyo M (1989) Occurrence and distribution of the hydrothermal ore deposits at the Izena Hole in the Okinawa Trough - summary of the knowledge in 1988-. JAMSTEC Deepsea Res 5:183-189 (in Japanese with English abstract)

Nakano H, Okamoto K, Ishibashi J-I, Noguchi T (2008) Chemical signature of submarine hydrothermal deposits collected from the Hatoma Koll in southern Okinawa trough backarc basin. Abstract, MRD03316P, 33rd International Geological Congress, Oslo, August 6-14, 2008

Nakashima K, Sakai H, Yoshida H, Chiba H, Tanaka Y, Gamo T, Ishibashi J, Tsunogai U (1995) Hydrothermal mineralization at the Okinawa Trough. In: Sakai H, Nozaki Y (eds) Biogeochemical processes and ocean flux in the Western Pacific. Terra Scientific Publication, Tokyo, pp 487-508

Nash DF (1979) The geological development of the North Okinawa Trough area from Neogene times to recent. J Japan Assoc Petrol Tech 44:109-119

Noguchi T, Oomori T, Tanahara A, Taira N, Takada J, Taira H (2007) Chemical composition of hydrothermal ores from Mid-Okinawa Trough and Suiyo Seamount determined by neutron activation analysis. Geochem J 41:141-148

Noguchi T, Shinjo R, Ito M, Takada J, Oomori T (2011) Barite geochemistry from hydrothermal chimneys of the Okinawa Trough: insight into chimney formation and fluid/sediment interaction. J Min Petrol Sci 106:26-35

Nozaki T, Ishibashi J, Shimada K, Takaya Y, Kato Y, Kawagucci S, Shibuya T, Takai K (2013) Geochemical signature of the "zero-age chimney" formed on artificial hydrothermal vents created by IODP Exp. 331 in the Iheya North field, Okinawa Trough, Proceedings of the 12th Biennial SGA Meeting, 12-15 August 2013, Uppsala, Sweden, ISBN 978-91-7403-207-9, p 561

Ohmoto H (1996) Formation of volcanogenic massive sulfide deposits: the Kuroko next term perspective. Ore Geol Rev 10:135-177. doi:10.1016/0169-1368(95)00021-6

Ohmoto H, Skinner BJ (eds) (1983) The Kuroko and related volcanogenic massive sulfide deposits. Econ Geol Monogr 5:604

Oikawa M, Nishizawa A, Kaneda K, Horiuchi D (2009) Seismic crustal structure along the Okinawa Trough axis. Abstract, The Seismological Society of Japan (SSJ) 2009 Fall Meeting, Kyoto, Oct 21-23, 2009

Okamoto K, Ishibashi J, Motomura Y, Yamanaka T, Fujikura K (2002) Mineralogical studies of hydrothermal deposits collected from the Dai-Yon Yonaguni Knoll and the Hatoma Knoll in the Okinawa Trough. JAMSTEC Deepsea Res 21:75-81 (in Japanese with English abstract)

Ooki M, Miyoshi Y, Shimada K, Ishibashi J-I, Nozaki T (2012) Mineralogy and geochemistry of hydrothermal ores collected from active hydrothermal fields in shallow water depth. In: Proceedings of Japan Geoscience Union Meeting 2012, BBG21P09 (abstract)
Oshida A, Tamaki K, Kimura M (1992) Origin of the magnetic anomalies in the southern Okinawa Trough. J Geomag Geoelectr 44:345-359

Osozawa S, Su Z-H, Oba Y, Yagi T, Watanabe Y, Wakabayashi J (2013) Vicariant speciation due to $1.55 \mathrm{Ma}$ isolation of the Ryukyu islands, Japan, based on geological and GenBank data. Entomolog Sci 16:267-277. doi:10.1111/ens.12037

Otubo M, Hayashi D (2003) Neotectonics in southern Ryukyu arc by means of paleostress analysis. Bull Fac Sci Univ Ryukyus 76:1-73

Park J-O, Tokuyama H, Shinohara M, Suyehiro K, Taira A (1998) Seismic record of tectonic evolution and backarc rifting in the southern Ryukyu island arc system. Tectonophysics 294:21-42

Pokrovski GS, Roux J, Harrichoury JC (2005) Fluid density control on vapor-liquid partitioning of metals in hydrothermal systems. Geology 33:657-660

Ryan BF, Carbotte SM, Coplan JO, O'Hara S, Melkonian A, Arko R, Weissel RA, Ferrini V, Goodwillie A, Nitsche F, Bonczkowski J, Zemsky R (2009) Global multi-resolution topography synthesis. Geochem Geophys Geosyst 10, Q03014. doi:10.1029/ 2008GC002332

Sakai H, Gamo T, Kim E-S, Tsutsumi M, Tanaka T, Ishibashi J, Wakita H, Yamano M, Oomori T (1990) Venting of carbon dioxide-rich fluid and hydrate formation in mid-Okinawa Trough Backarc Basin. Science 248:1093-1096

Sato T (1974) Distribution and geological setting of the Kuroko deposits. Min Geol Spec Issue 6:1-9

Shikazono T (2003) Geochemical and tectonic evolution of arc-backarc hydrothermal systems implication for the origin of kuroko and epithermal vein-type mineralizations and the global geochemical cycle. Elsevier, Amsterdam, p 466

Shikazono T, Kusakabe M (1999) Mineralogical characteristics and formation mechanism of sulfate-sulfide chimneys from Kuroko area, Mariana Trough and mid-ocean ridges. Res Geol Spec Issue 20:1344-1698

Shinjo R (1999) Geochemistry of high Mg andesites and the tectonic evolution of the Okinawa Trough-Ryukyu arc system. Chem Geol 157:69-88

Shinjo R, Kato Y (2000) Geochemical constraints on the origin of bimodal magmatism at the Okinawa Trough, an incipient back-arc basin. Lithosphere 54:117-137

Shinjo R, Chung S-L, Kato Y, Kimura M (1999) Geochemical and Sr$\mathrm{Nd}$ isotopic characteristics of volcanic rocks from the Okinawa Trough and Ryukyu Arc: implications for the evolution of a young, intracontinental back arc basin. J Geophys Res 104:10591-10608. doi:10.1029/1999JB900040

Shinjo R, Machiyama H, Maki Y, Motoyama I, Toyama G, Hokakubo S, Chung S-L (2001) Outline of SHINKAI-2000 dive surveys at the westernmost part of the Okinawa Trough and the Kuroshima Knoll preliminary report of the NT00-06 Leg-1 Cruise. JAMSTEC Deepsea Res 19:109-121 (in Japanese with English abstract)

Shitashima K, Maeda Y, Koike Y, Ohsumi T (2007) Natural analogue of the rise and dissolution of liquid $\mathrm{CO}_{2}$ in the ocean. Int J Greenhouse Gas Control 2:95-104. doi:10.1016/S1750-5836(07)00092-8

Sibuet J-C, Letouzey J, Barbier F, Charvet J, Foucher J-P, Hilde T, Kimura M, Ling-Yun C, Marsset B, Muller C, Stephan J-F (1987) Back arc extension in the Okinawa Trough. J Geophys Res 92:14041-14063. doi:10.1029/JB092iB13p14041

Sibuet J-C, Deffontaines B, Hsu S-K, Thareau N, Le Formal J-P, Liu CS, ACT Party (1998) Okinawa trough backarc basin: early tectonic and magmatic evolution. J Geophys Res 103:30245-30267

Suzuki R, Ishibashi J-I, Nakaseama M, Konno U, Tsunogai U, Gena K, Chiba H (2008) Diverse range of mineralization induced by phase separation of hydrothermal fluid: a case study of the Yonaguni IV hydrothermal field in the Okinawa Trough Backarc Basin. Res Geol 58:267-288. doi:10.1111/j.1751-3928.2008.00061.x 
Takai K, Nunoura T, Ishibashi J-I, Lupton J, Suzuki R, Hamasaki H, Ueno Y, Kawagucci S, Gamo T, Suzuki Y, Hirayama H, Horikoshi $\mathrm{K}$ (2008) Variability in the microbial communities and hydrothermal fluid chemistry at the newly discovered Mariner hydrothermal field, southern Lau Basin. J Geophys Res 113, G02031. doi:10. 1029/2007JG000636

Takai K, Mottl MJ, Nielsen SH, The Expedition 331 Scientists (2011) Proceedings of IODP, 331: Tokyo (Integrated Ocean Drilling Program Management International, Inc.). doi:10.2204/iodp. proc.331.2011

Takai K, Mottl MJ, Nielsen SH, The Expedition 331 Scientists (2012) IODP expedition 331: strong and expansive subseafloor hydrothermal activities in the Okinawa Trough. Sci Dril 13:19-27. doi:10.2204/iodp.sd.13.03.2011

Tsuji T, Takai K, Oiwane H, Nakamura Y, Masaki Y, Kumagai H, Kinoshita M, Yamamoto F, Okano T, Kuramoto S (2012) Hydrothermal fluid flow system around the Iheya North Knoll in the midOkinawa trough based on seismic reflection data. J Volcanol Geotherm Res 213-214:41-50

Ueno H, Hamasaki H, Murakawa Y, Kitazono S, Takeda T (2003) Ore and gangue minerals of sulfide chimneys from the North Knoll, Iheya Ridge, Okinawa Trough, Japan. JAMSTEC Deepsea Res 22:49-62

Urabe T, Kubota H (2004) About this issue: Kuroko deposits revisited after the discovery of their modern analogues on submarine arc volcanoes. Res Geol 54:385-386

Urabe T, Marumo K (1991) A new model for Kuroko-type deposits of Japan. Episodes 14:246-251

Wang C, Yang M-L, Chou C-P, Chang Y-C, Lee C-S (2000) Westward extension of the Okinawa Trough at its western end in the northern Taiwan area: bathymetric and seismological evidence. Terrest Atmos Ocean 11:459-480

Watanabe K (2001) Mapping the hydrothermal activity area on the Hatoma Knoll in the southern Okinawa Trough. JAMSTEC Deepsea Res 19:87-94 (in Japanese with English abstract)

Watanabe K, Shibata A, Furukawa H, Kajimura T (1995) Topography of submarine volcanoes off the North-Northeast Coast of Iriomote island, the Ryukyu Islands. Kazan Ser 2(40):91-97 (in Japanese with English abstract)
Watanabe M, Hoshino K, Shiokawa R, Takaoka Y, Fukumoto H, Shibata Y, Shinjo R, Oomori T (2006) Metallic mineralization associated with pillow basalts in the Yaeyama Central Graben, Southern Okinawa Trough, Japan. JAMSTEC Rep Res Dev 3:1-8

Yamada R, Yoshida T (2011) Relationships between Kuroko volcanogenic massive sulfide (VMS) deposits, felsic volcanism, and island arc development in the northeast Honshu arc. Jpn Min Deposita 46:431-448

Yamano M, Uyeda S, Kinoshita H, Hilde TWC (1986) Report on DELP 1984 cruises in the middle Okinawa Trough Part 4: heat flow measurements. Bull ERI Univ Tokyo 61:251-267

Yeats C, Hollis SP (2013) Actively forming Kuroko-style massive sulfide mineralisation and hydrothermal alteration at Iheya North, Okinawa Trough. Abstract, Goldschmidt Conference 2013, Florence, August 25-30, 2013

Yeats C, Hollis S, Corona JC, Expedition 331 Shipboard Scientific Party (2012) Actively forming Kuroko-style massive sulfide mineralization and hydrothermal alteration at Iheya North, Okinawa Trough -key petrological results of IODP Expedition 331. Abstract, 34th International Geological Congress, Brisbane, August 5-10, 2012

Yokose H, Sato H, Kobayashi T, Yoshimura H, Morii Y, Yamawaki N (2009) Evidence of recent hydrothermal activity in the Amami caldera: discovery of Fe-Mn oxide crusts enriched in As and Mo. Proceedings of Japan Geoscience Union Meeting 2009, R219-008 (abstract)

Yokose H, Yoshimura H, Morii Y, Kobayashi T (2010) Volcanic chain of the western Okinawa Trough margin: discovery of a quaternary shoshonitic rock. In: Proceedings of Japan Geoscience Union Meeting 2011, SCG086-28 (abstract)

Zeng ZG, Yu SX, Yin XB, Wang XY, Zhang GL, Wang XM, Chen DG (2009) Element enrichment and U-series isotopic characteristics of the hydrothermal sulfides at Jade site in the Okinawa Trough. Sci China Ser D Earth Sci 52:913-924. doi:10.1007/s11430-0090107-y

Zierenberg RA, Miller DJ (2000) Overview of ocean drilling program Leg 169: sedimented ridges II. In: Zierenberg RA, Fouquet Y, Miller DJ, Normark WR (eds) Proc ODP Sci Res 169: College Station, TX (Ocean Drilling Program), pp 1-39 